Est $\mathrm{Ag} 35$ (2000) 5-47

\title{
Jesús y los cínicos
}

Francamente no suena bien asociar a Jesús con los cínicos. Cualquier diccionario de sinónimos nos informa que equivale a cara dura, desvergonzado, falto de escrúpulos, desaprensivo. Más tranquilo queda quien consulte un diccionario de la lengua, pues se le advierte que cínico se aplica "a los filósofos griegos de la escuela de Antístenes de los que el más destacado es Diógenes"1. La mala impresión que el término proporciona dependerá de la opinión que se tenga sobre esa escuela grecorromana. Y ciertamente los cínicos han gozado siempre de admiración en los círculos ilustrados: la actitud contracultural, la libertad individual frente a la norma, la rebeldía frente al Estado, llevar una vida más natural frente a la sofisticación de la sociedad son actitudes que siempre han despertado simpatías. La propuesta de presentar a Jesús cínico no parece ser en principio un accidente de la moda, aunque algo tiene que ver indudablemente. Y es, como advierte García Gual "éstos son buenos tiempos para el cinismo"2. El cinismo es un efecto del agobio y pesadez que produce la cultura y los convencionalismos que coartan la libertad individual.

\section{Tema con cierta historia}

La relación del cinismo con el cristianismo viene de lejos. Es en la época patrística cuando por vez primera cristianos y cínicos aparecen relacionados en los textos 3 . En general predominan las reservas de los primeros contra los segundos. Las críticas que les hacen no son ciertamente originales. Acusar a

1. M. Moliner, Diccionario del uso del español. Madrid 1982, I, 632.

2. C. GARCía GuAL, La secta del perro; Diógenes LAERCIO, Vidas de los filósofos cínicos. Madrid 1987, 11.

3. G. DoRIVAL, "L'Image des Cyniques chez les Pères Grecs": Le Cynisme ancien et ses prolongements. Paris, 1993 419-443; H. D. BETZ, "Jesus and the Cynics: Survey and Analysis of a Hypotesis": The Journal of Religion 74(1994)453-475, espec. 460-461. 
los cínicos de indiferencia en el terreno ético, hipocresía, vanagloria o perversión es común en las fuentes paganas que los Padres acogen con asiduidad. Pero hay varios, y esto es lo que conviene resaltar, que alaban francamente la pobreza practicada por los cínicos y el desprendimiento de los bienes de este mundo. Aquí es donde Padres como Juan Crisóstomo, Basilio de Cesarea y Nilo de Ancira ven una semejanza notable. De este parecido eran conscientes algunos autores paganos, quienes critican a los cristianos por las semejanzas que advierten con los cínicos 4 . Celso, por ejemplo, observa que los cristianos se portan como charlatanes que predican públicamente y congregan un gran número de oyentes sin selección alguna5. Orígenes le contesta negando parecido alguno con los charlatanes y le invita a que observe el contenido diverso de las predicaciones y en todo caso- le dice- ya quisieran los filósofos congregar tal número de oyentes; concretamente le señala que eso hacen los filósofos cínicos y nadie ni siquiera Celso reprocha ese proceder a tales filósofos. En otro lugar rebatiendo a Celso que acusa a Jesús de "no haberse mostrado puro de todos los males", Orígenes le rebate que está de acuerdo con él si entiende por males la pobreza y la cruz; pero le recuerda a Celso que muchos filósofos griegos abrazaron voluntariamente la pobreza. Y le cita expresamente a Demócrito, Crates y Diógenes, estos dos últimos filósofos cínicos reconocidos 6 . Orígenes, al parecer, no ve ningún inconveniente en asociar a Jesús con los cínicos en este aspecto.

Como el cinismo desaparece en el VI, ya no hay en el curso de la historia comparaciones explícitas. Hay que esperar a la época moderna, concretamente al s. XIX para que surja de nuevo la atención a este tema. No merece la pena detenerse en Nietzsche, pues asocia el cinismo a un cristianismo y a un Jesús no religioso artificialmente construido ${ }^{7}$. Ya en este siglo las semejanzas son descubiertas por los historiadores de la filosofía como una constatación neutral. Tal es el caso del inglés D. B. Dudley. A él se debe el auge de los estudios sobre la filosofía cínica ${ }^{8}$. En este caso se trataba de mostrar que ciertos aspectos del cinismo se asemejan a algunas ideas cristianas.

4. Recoge los textos y los comenta F. G. DownING, Cynics and Christian Origins. Edinburgh 1992, 169-301.

5. ORÍGENES, Contra Cels. III, 50.

6. ID. Ib. II, 40.

7. H. D. BETZ, "Jesus and the Cynics", 465-470.

8. A History of Cynicism from Diogenes to the 6th Century A.D. London 1937,173-175, 204-207. 
Es a partir de la década de los 70 cuando estas semejanzas se han desarrollado ampliamente y por exégetas.

El primero que establece relación es, al parecer, G. Theissen. Proponiendo su conocida teoría sobre el radicalismo itinerante de los primeros discípulos, señala el paralelismo con los filósofos cínicos. El ethos de ambos grupos (sin patria, sin familia y sin posesiones) es muy semejante. Expresamente señala que se trata de semejanzas estructurales, y no de relaciones históricas, aunque sabe que en Transjordania, concretamente en Gadara hubo cínicos famosos ${ }^{9}$. Incluso señala que la renuncia a la bolsa, al bastón, al pan y al dinero que Jesús exige de sus discípulos, tiende probablemente a evitar que se les confunda con los cínicos. Theissen extiende la semejanza a Jesús, ya que afirma "que la situación social de Jesús y la de una rama del cristianismo primitivo son semejantes: Jesús fue el primer carismático ambulante"10.

J. E. Stambaugh y D. L. Balch aceptan esta semejanza, aunque se distancian de Theissen cuando señalan que la ética de la carencia de hogar no era una opción libremente elegida sino más bien un desarraigo por causas políticas y económicas ${ }^{11}$. Cínicos y ciertos cristianos enseñaron y vivieron un estilo de vida ascético. Tales paralelismos se consideran fundamentados en la lectura de Lc 10,1-16, pasaje que en este contexto es especialmente valorado12. Pero estos autores indican luego que las razones esgrimidas por los cristianos a favor de la renuncia a las riquezas son totalmente distintas y con otra finalidad.

En la década los 80 se ha dado un paso más. La riqueza de paralelos entre Jesús y el cinismo se ha considerado tan importante que se ha afirmado la relación sustancial e influencia directa del cinismo sobre la primitiva comunidad cristiana y sobre Jesús mismo. Tal es la opinión presentada por el inglés F. Gerald Downing quien desde 1982 en numerosas publicaciones ha defen-

9. Estudios de Sociología del Cristianismo primitivo. Salamanca 1985, 24-25.

10. G. Theissen, Estudios, 24-28. El original es de los años 1971-1972. Pero se trata de ciertas semejanzas. En el relato histórico-ficticio de La Sombra del Galileo, el protagonista debe redactar un relato sobre Jesús dirigido a los romanos; se le ocurre la idea de compararlo a los cínicos itinerantes; enumera los puntos de contacto entre los dos: nada de familia, nada de profesión, nada de riqueza, amor al prójimo y a los enemigos... etc., pero el autor es consciente de que el parecido es imperfecto y por ello dice que Jesús es también profeta. (El punto dudoso es si los cínicos enseñaban el amor al prójimo y a los enemigos).

11. El Nuevo Testamento en su entorno social. Bilbao, 1993, 133.

12. Véase también M. HENGEL, Seguimiento y carisma. La radicalidad de la llamada de Jesús. Santander 1981, 46-48. 
dido y expuesto su tesis: ciertos grupos cristianos - dice él- no sólo le dieron un look a la predicación de Jesús, sino que Jesús mismo se inspiró en el cinismo, de tal manera que el mejor modelo para entender la figura de Jesús es la del filósofo cínico.

A la misma opinión, se han adherido de manera más radical y partiendo de otros argumentos, varios miembros del Jesus Seminar ${ }^{13}$ a partir del año 198614. Entre ellos cabe destacar a L. E. Vaage, R. Cameron, B. Mack, J. D. Crossan. Hay varias y profundas diferencias entre la postura de Downing y la tesis de los autores americanos.

Antes veamos brevemente lo que significó el cinismo como escuela filosófica en la antigüedad.

\section{El Cinismo}

A pesar de la creciente atención que se presta a los cínicos, quedan aún muchas incógnitas como, por ejemplo, las siguientes: continuidad o no del cinismo desde el s. IV a. C. hasta el s. VI d. C., relación entre los cínicos antiguos del s. IV y III a. C. y los cínicos de la época imperial, relación entre los cínicos y los estoicos y en fin el problema de las fuentes cínicas y qué valor darle a cada una.

\section{1. Fuentes}

Las fuentes literarias de los cínicos ni son abundantes ni claras ${ }^{15}$. Precisamente el gran problema del cinismo es no tener fuentes fiables. Las obras más importantes de la literatura cínica- que al parecer fueron numerosas- han desaparecido; sólo se conservan escasos fragmentos citados por intermediarios, simpatizantes o enemigos.

13. Sobre esto grupo véase C. MIelgo, "El Jesús histórico y el Jesus Seminar": Estudio Agustiniano 32(1997)171-216.

14. Esta fecha apunta J. M. RoBinson, "Galilean Upstarts: A Sot's Cynical Disciples: Sayings of Jesus: Canonical and Non-Canonical. Essays in Honour of Tjitze Baarda; edit. by W. L. Petersen, J. S. Vos, H.J. de JoNGE. Leiden 1997, 223.

15. Recoge las fuentes (fragmentos y testimonios) acerca del primer cinismo con comentario G. Giannantoni, Socratis et Socraticorum Reliquiae. Napoli 1990. Vo.II. 135589. Comenta los fragmentos en el vol. IV, pp.195-583. 
La principal fuente es sin duda el Libro VI de la Vida de las Filósofos de Diógenes Laercio, estoico, que vivió en el s. III d. C. Este no escribe la historia de la filosofía cínica sino un conjunto de anécdotas o chrias, procedentes de colecciones anteriores, pertenecientes a los cínicos de la primera época: de Antístenes (cuya pertenencia al cinismo hoy ordinariamente se niega) y sobre todo de Diógenes (404-323); más brevemente habla de los cínicos siguientes, todos ellos del s. IV y III a. C. Dada la distancia temporal (más de cinco siglos) entre Diógenes Laercio y los primeros cínicos de los que habla, nadie puede garantizar la autenticidad de las anécdotas; de hecho algunos dichos se recogen en más de una forma o son atribuidos a más de un filósofo.

Hay que mencionar también las Cartas Cínicas ${ }^{16}$. Se trata de cartas ficticias atribuidas a cínicos antiguos y a otros personajes. Sus verdaderos autores son desconocidos y el tiempo de composición es oscuro: oscila desde el s. III a C. hasta el s. II d. C. Predominan las de la época de Augusto.

Nos informan también del cinismo Dión de Prusa (ca.40-120 d. C.) y Luciano de Samosata (120-180 d. C.). Los dos hablan de personajes cínicos; el primero lo es, aunque presenta un cinismo edulcorado ${ }^{17}$; el segundo es, más bien, un sofista que detesta al cínico Peregrino (convertido al cristianismo que luego abandonó) y alaba con entusiasmo al también cínico Demonacte, pero porque no se comporta al menos en su porte exterior como cínico. En el fondo Luciano odiaba a los cínicos. Ni Peregrino ni Demonacte nos dejaron nada escrito. El único escritor cínico del s. II es Enómao de Gadara; su obra recogida por Eusebio no parece haber tenido mucho éxito.

Nos dan noticias también de los cínicos los estoicos Epicteto ${ }^{18}$ (ca. 50-138 d. C.) y Séneca (4-65 d. C.), que hablan del cinismo de su tiempo; el primero con elogios, el segundo no tanto. Ambos presentan un cinismo más estoico que otra cosa; por contra el emperador Juliano (s. IV) desprecia a los cínicos contemporáneos tanto como admira a los cínicos antiguos ${ }^{19}$.

16. A. J. MAlHerbe, The Cynic Epistles. Missoula 1977; E. Mueseler, Die Kynikerbriefe. Paderborn 1994.

17. "Dion a voulu offrir avec son Diogène un modèle philosophique et moral acceptable pour ses auditeurs, un modèle certes ennobli par la distance, mais au fond très proche de lui même": F. JouAN, "Le Diogène de Dion Chrysostome": Le Cynisme Ancien et ses Prolongements. Actes du Colloque International du CNRS (Paris 22-25 Juillet 1991), M. O. Galet-Caze et R. Goulet (Dir). París 1993, 397.

18. Disertaciones, III, XXII y su propio resumen en IV, VIII, 40-43.

19. Hay menciones y alusiones al cinismo, además, en Cicerón, Varrón, Horacio, Filón de Alejandría, Musonio Rufo, Plutarco, Elio Arístides, etc. 
Lo que resalta es la poca literatura producida por ellos y conservada hasta hoy; también es digno de notarse que conozcamos el cinismo antiguo a través de las informaciones que nos proporcionan autores pertenecientes a la época imperial. La razón de esto sin duda hay que buscarla en el hecho de que el cinismo no fue una escuela, sino un modo de vida puesto en práctica por una serie sucesiva de personalidades cínicas. Resulta finalmente chocante que el primero que nos informa sea Filodemo de Gadara conocido epicureista del s. I. y enemigo de los cínicos.

En principio parece acertado distinguir dos fases en el tiempo y en el talante en la historia de esta escuela. El cinismo primitivo de los s. IV y III a. C. debe separarse de su continuación, fiel a grandes rasgos al primer cinismo pero distinto, de los s. I y II d. C. Estas dos fases están separadas por un vacío de personalidades cínicas, que se extiende durante los s. II y I a. C. y la primera mitad del s. I d. C. Entre Cércidas de Megalópolis (ca. 290-220 a. C.) y Demetrio (s. I d. C.) no se menciona cínico alguno. ¿Es un vacío de información o es ausencia de cinismo?. Se discute, aunque se ve difícil que se deba a la falta de noticias cuando nos son conocidas más de 130 figuras cínicas ${ }^{20}$. Evidentemente los partidarios de un Jesús cínico defienden la continuidad cínica a través de los siglos; argumentos no les faltan; lo concluyen de las citas de Cicerón ${ }^{21}$ y otros autores 22

La primera fase se desarrolla en Grecia y es un cinismo más radical y exasperado; predominan figuras carismáticas. La segunda fase se desarrolla en las grandes ciudades del imperio romano, Roma, Alejandría, Constantinopla etc. Aunque no faltaron personalidades de relieve, fue más común un cinismo como praxis filosófica colectiva ${ }^{23}$.

\section{2. Doctrina.}

Impropiamente se aplica este término al cinismo, pues, es más bien un

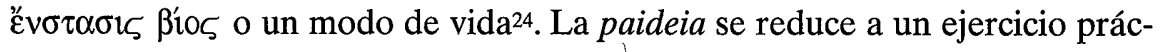

20. M.-O. Goulet-Caze ("A Comprehensive Catalogue of Known Cynic Philosophers": The Cynics: The Movement in Antiquity and Its Legacy, edit. by R. BRACHT-BRANHAM and M.- O. GouLET-CAZE. Berkeley 1996. 389-413) ofrece la lista de cínicos.

21. De Officiis, L. I, 35, 128; L.I, 41, 148.

22. Véase F. G. Downing, Cynics and Christian Origins, 60 ss.

23. The Cynics 6-7.

24. Diógenes LAERcio, Vida de los Fillósofos, VI, 103. Diógenes piensa que es una verdadera filosofía. 
tico de ascesis con muy poca base teórica. Aceptan desde luego la doctrina socrática sobre la felicidad que consiste en el apagamiento de los deseos. El deseo no satisfecho es la causa de la infelicidad. Como los deseos no pueden totalmente satisfacerse, pues no depende únicamente del esfuerzo personal, hay que contar en efecto con muchos imponderables aleatorios, entre ellos la fortuna, forzoso es aplicarse a la otra parte, es decir, a reducir y controlar los deseos. Reducir las necesidades al mínimo, he aquí su ideal. Los dioses no tie-

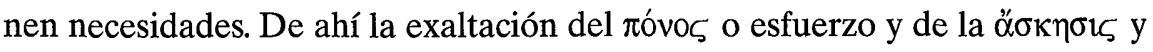
la admiración por Hércules, su ídolo admirado.

Muchas necesidades se eliminan si se atiende al otro principio que constituye el pilar del cinismo. Se trata de la oposición entre $\phi \dot{v} \sigma 1 \zeta$ y vó $\mu$ o , entre

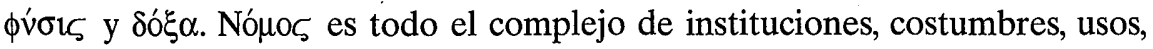
buenas maneras, opiniones corrientes que por ser diferentes en cada pueblo, son convencionales y pura imposición. Ya anteriormente los sofistas se habían fijado en esta oposición. El cinismo da un paso más: declara la guerra a la civilización y todo lo convencional y proclama la vuelta a la naturaleza, de cuyas ataduras el cínico no puede librarse. Busca así un atajo para la felicidad25. De un plumazo suprime las ataduras que impiden la libertad individual y por tanto la felicidad personal, que el cínico busca afanosamente. La naturaleza provee una norma ética que se observa en los animales.

De esta convicción filosófica surgía una especie de vocación misionera dirigida a la sociedad. Hacían lo que podían para abrir los ojos de los demás. Esto llevaba consigo hablar en alta voz en la plaza del mercado, con arengas, conducta social inaceptable, como usar lenguaje violento, ropas socias, actos de la naturaleza en público (hacer de cuerpo o practicar el sexo), fingir locura, etc.

Su porte exterior llamaba la atención. Iban descalzos, pelo y barba larga, manto basto y andrajoso, un bastón y un morral donde llevaban las escasas pertenencias. Esto era su uniforme casi oficial, aunque no todos lo usaran; lo importante era llevar un atuendo y un modo de vida de mendigo que apareciera distinto y antisocial. Se dejaban notar por su actitud práctica en lo que se refiere al vestido, la alimentación y lugar de residencia. "Hacer cualquier cosa en cualquier lugar" era la divisa del fundador del cinismo 26 ; lo que comportaba desfachatez, falta de vergüenza, la óv $\alpha 1 \delta \varepsilon^{\prime} \alpha$ o falta de pudor.

El cínico no hace nada para el bien común ${ }^{27}$. Era esencialmente individualista y en gran parte antisocial reclamando independencia de toda nación,

25. Diógenes Laercio, VI, 104; Ps. Crates, Ep. 21.

26. Diógenes LAERCIO, VI, 22. 
patria o comunidad. Su cosmopolitismo no es positivo, como si apuntara a una fraternidad universal, sino meramente negativo, es decir desarraigo de toda comunidad humana ${ }^{28}$. No es que rechace la polis por la patria universal. Tampoco critica a las religiones, porque tenga aspiraciones a una religión más elevada; el rechazo del matrimonio es porque quiere evitar compromisos; las necesidades sexuales deben ser satisfechas de inmediato si hay oportunidad. Familia, patria y religión son tres instancias sociales rechazadas porque se oponen a la naturaleza.

Parece que tuvieron éxito; en caso contrario no se explicaría la permanencia del cinismo durante un milenio. Como resultaban molestos a las clases sociales y al poder político ${ }^{29}$, su éxito probablemente se debió a que ofrecían a los pobres un ideal práctico de autonomía de la voluntad que llevaba esperanza a la masa de oprimidos. Para la capa amplia social de marginados ser cínico o mejor ser tenido por cínico era un timbre de gloria y desde luego más provechoso que ser un simple mendigo.

\section{3. Variedad del Cinismo}

La variedad cínica es un hecho reconocido ampliamente ${ }^{30}$. Tal diversidad no debe extrañar por varias razones. En primer lugar el cinismo se extiende a lo largo de un milenio y es natural que evolucionara como también cambiaba la sociedad.

Pero hay otra razón más importante. Como la vía cínica tiene poca base teórica y es más un modo de vida, se explica que diera lugar a diferencias grandes en la práctica cínica. Todo depende de hasta dónde el cínico considere que deba extender su seguimiento de la naturaleza. Hemos visto que los principios del cínico podían resumirse en estas frases: Vivir conforme a la naturaleza y en oposición a lo que la gente da como admitido; comprometerse en una ascesis práctica en busca de la autarquía, practicar y proclamar una crítica contracultural. Todo ello comportaba un variado abanico de compromisos concretos.

En principio puede decirse que el cinismo sufrió un constante lavado, suprimiendo los rasgos más chocantes y ofensivos. Los simpatizantes tardíos

27. C. GARCÍA GUAL. La secta del perro, 60.

28. G. Giannantoni, Socratis, IV, 544.

29. Fueron expulsados de Roma repetidas veces durante el s. I d. C.

30. DUDLEY, $A$ History of Cynicism, 1937, 53. 
como el Emperador Juliano y Epicteto llevan a cabo esta labor suavizadora con decisión, pero este empeño había ya comenzado antes ${ }^{31}$

Si de Diógenes se afirma que hacía sus necesidades corporales en público (las obras de Deméter y de Afrodita ${ }^{32}$ ) y se muestra hiriente e insultante (escupir en la cara del que le invita ${ }^{33}$ ); los siguientes se muestran más delicados. Diógenes rechaza el matrimonio, no por ello es célibe; al contrario, practica el sexo, cuando se le ofrece ${ }^{34}$, mientras que Demonacte rechaza el matrimonio pero no se le conocen aventuras ${ }^{35}$ y Dión de Prusa fustiga el adulterio, prostitución y la vida licenciosa en general36. Según sus enemigos (Filodemo de Gadara) Diógenes admitió la antropofagia y el incesto; no se sabe que los demás cínicos pensaran así.

Crates es recordado como figura benevolente y filantrópica, árbitro en las querellas familiares ${ }^{37}$. Demonacte practicaba lo primero ${ }^{38}$, pero no parece que le imitara en lo segundo ${ }^{39}$.

Enómao de Gadara es contemporáneo de Peregrino y puede verse en él un contramodelo del segundo. Enómao, según Juliano, blasfemaba, despreciaba la fe, los oráculos de Delfos, etc. ${ }^{40}$. Nada de esto se encuentra en Peregrino ${ }^{41}$. Juliano elimina del cínico la negación de la amistad, del matrimonio, de la procreación y del compromiso político ${ }^{42}$.

Esta diferencia se observa también en el aspecto exterior. Se suele decir que se caracterizaban por su indumentaria. Vestir una capa doblada y raída (sin túnica), morral, bastón y dirigirse a todo el mundo burlonamente podía ser suficiente para ser tenido como cínico. "El zurrón, con el manto de lana y 320 .

31. M. BILLERBECH, "Le cynisme idealisé d'Épictète a Julien: Le Cynism Ancien, 319-

32. Diógenes Laercio, Vidas, VI, 69. B. Mack tilda a Diógenes de "repugnante figura" (El Evangelio Perdido. Barcelona 1994, 24).

33. Diógenes LAERCIO, Vidas, VI, 32.

34. DióGenes LAERCio, Vidas, VI, 72.

35. LuCiano de Samosata, Demonacte, 56.

36. Discursos, VII, 133-152.

37. DIÓGENES LAERCIO, Vidas, 86-87.

38. LuCiano de SAmosata, Demonacte, 9-10.

39. Ib. 27.

40. Juliano, Contra el Cínico Heraclio, 5-6.

41. Ch.P. Jones, "Cynisme et sagesse barbare. Le cas de Pérégrinus Proteus: Le Cynisme ancien, 316.

42. J. Bouffartige, "Le Cynisme dans le Cursus Philosophique au IV siècle. Le témoignage de l'Empereur Julien": Le Cynisme ancien, 350. 
el bastón se convirtió después de Diógenes en el retrato habitual del cínico"43. Epicteto decía que se les podía conocer por el vestido y su actitud chillona, que por cierto desaprueba.

Pero tampoco en esto hay acuerdo. En la vida de Demonacte se habla de un cínico que llevaba una maza y no bastón ${ }^{44}$. Diógenes el cínico sólo usó bastón cuando estaba enfermo y en su vejez. Por otra parte la capa era también propia de los pitagóricos ${ }^{45}$. Por lo demás el bastón lo llevaba todo ateniense ${ }^{46}$

También se suele afirmar que la itinerancia era característica de los cínicos. Pero de nuevo aquí las fuentes son ambiguas. Diógenes, Crates y Demonacte vivían en Atenas ${ }^{47}$. Dión de Prusa vivía en Roma y solamente al ser desterrado en el 82 d. C. por Domiciano comenzó una vida itinerante que duró 14 años. Al lado de estos ejemplos había otros que caminaban como Peregrino o el Diógenes de las Cartas o los cínicos populares de Luciano.

\section{4. Religión}

Para nuestro tema queremos llamar la atención sobre este punto.

Es sabido que en la época helenista la religión en gran parte era superstición, sobre todo la religión popular. Por ello era común entre la gente letrada despreciar y criticar las prácticas piadosas. En este punto sí estaban de acuerdo los cínicos con el resto de los filósofos. Es más los cínicos tenían más motivos que nadie para criticarlas. La religión popular y sus prácticas provie-

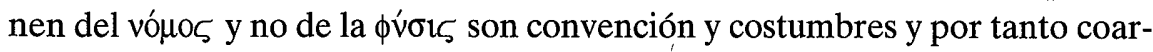
tan la libertad.

Pero los cínicos van más allá. Filodemo de Gadara dice que muchos cínicos estiman felices a los animales, porque entre otras cosas, no conocen ni siquiera a los dioses, esos dioses que nos inspiran tanto miedo. En este punto

43. G. Giannantoni, Socratis, IV, 502; Luciano de SAmosata da por supuesto que la alforja, bastón y manto son las características del cínico (Sobre la muerte de Peregrino, 24). Theissen señala que la prohibición de Jesús hecha a sus seguidores de usar el zurrón y el bastón es para distinguirse de los cínicos. Pero R. A. Horsley lo niega con razón (Jesus and the Spiral of Violence. Minneapolis 1993. 230).

44. Luciano de Samosata, Demonacte, 49.

45. G. GIANNANTONI, Socratis, IV, 501.

46. G. Giannantoni, ib. IV, 502.

47. La afirmación de Dión de Prusa de que Diógenes pasaba el invierno en Atenas y el verano en Corinto es legendaria (Véase G. GiannANTONI, Ib. IV, 459-460. 
son más radicales que los epicúreos y estoicos. Su horizonte es absolutamente terreno, no quieren saber de la transcendencia ni de una imagen providencialista del mundo, ni siquiera si este mundo fue creado. La idea de religión y de los dioses contradice su ideal de felicidad 48 . Pertenece a la leyenda presentar al cinismo antiguo y en concreto a Diógenes como teniendo una fe positiva en la divinidad 49 ; todavía va más allá Juliano el Emperador que presenta a Diógenes como $\varepsilon v \lambda \alpha \beta \eta \zeta$ o $\theta \varepsilon 0 \sigma \varepsilon \beta \eta \zeta$ “piadoso", y "temeroso de Dios" 50 . Los cínicos posteriores mantuvieron esta postura agnóstica frente a la religión 51 . La Religión era un asunto que no iba con ellos. Preferían no pronunciarse sobre temas que les trascendían. Rehusaban vivir con el miedo constante a los dioses. Ya esta manera de expresarse indica bastante bien el concepto que tenían de la religión. Hasta Demonacte tan alabado y estimado por Luciano niega la inmortalidad52.

Bajo este punto de vista es totalmente falso afirmar que "una imagen más equilibrada sería ver a los cínicos como análogos griegos de los profetas hebreos" 53 .

\section{Hipótesis recientes sobre Jesús cínico}

Desde dos campos se ha llegado a la opinión de presentar a Jesús como un filósofo cínico. De un lado F. G. Downing que en solitario y con decisión defiende la hipótesis cínica. Lo ha hecho con muchas publicaciones ${ }^{54}$. De otra parte están varios autores pertenecientes al Jesus Seminar. Las diferencias entre Downing y los americanos son profundas. Divergen en todo menos en calificar a Jesús de cínico. Veamos estas diferencias.

48. M. O. GoulET-GAZE, "Les premiers Cyniques et la religion": Le Cynisme Ancien, $142-143$.

49. Diógenes LaERCIO, Vidas, VI, 37, 105.

50. Disc. IX, 17; VII, 25; Véase G. Giannantoni, Socratis, IV, 549.

51. M. O. GOULET-CAZE, $I b ., 158$.

52. LuCIANo de Samosata, Demonacte, 32.

53. B. L. MACK, El Evangelio perdido, 124.

54. Las dos obras más importantes son Christ and the Cynics: Jesus and other Radical Preachers in First-century Tradition. Sheffield 1988; Cynics and Christian Origins. Edinburgh 1992. Ha escrito también muchos artículos; la mayor parte están recogidos en el último libro citado. 
a) Downing tiende a presentar a Jesús como un cínico judío, mientras que los americanos acentúan la ideología y cultura helenista de Jesús y de sus seguidores (Esto es más cierto de Mack y Vaage que de Crossan).

b) Downing expresamente dice que su sugerencia no elimina necesariamente la doctrina de la encarnación ${ }^{55}$. Atribuir rasgos cínicos o señalar contenidos judíos de su doctrina es indiferente respecto a lo que se afirme sobre su persona o significado.

c) La diferencia más notable aparece cuando se consideran los fundamentos de la hipótesis en Downing y en los otros. Downing parte de un estudio del cinismo, de sus representantes, de sus doctrinas, del género literario usado por ellos y constata paralelos estrechos con los escritos del N.T., particularmente con los Sinópticos. Es el cristianismo en su conjunto en su comportamiento y en su modo de pensar el que se parece a los cínicos.

Para los americanos el Jesús que se parece a los cínicos es un Jesús muy reducido, o si se quiere un sector, el más antiguo, según ellos, del cristianismo primitivo. La fuente más antigua del cristianismo es Q; descomponen esta fuente en dos estratos: Q1, o estrato más antiguo, reconstruido por ellos, es el que presenta a Jesús como sabio cínico; en este estrato no hay escatología ni apocalíptica, ni se habla del valor soteriológico de la muerte de Jesús ni se conoce su resurrección. Esta figura de Jesús, como sabio cínico, ve reafirmada su historicidad por el Evangelio de Tomás, donde también Jesús aparece como un sabio con una sabiduría no convencional. De ahí su identificación con un cínico. Acerca del cinismo se contentan con la opinión usual, que considera a los cínicos como disidentes culturales. De esta manera el primer Jesús estimado por los suyos era la figura de un sabio, figura que después se fue mitificando, llegándose a atribuirle la divinidad.

Downing rechaza abiertamente que en $\mathrm{Q}$ se puedan distinguir estratos por dos razones: a) Quienes defienden estratos ignoran el método de composición de las obras antiguas como si éstas fueran obra exclusiva de un autor y no de la comunidad. Los textos antiguos son proclamación más que escritos. El grupo controlaba la obra. Hoy no se suele pensar en la reacción que el público provocaría si percibía los cambios; y b) porque, como opinan muchos, no hay base suficiente para distinguir el estrato sapiencial del apocalíptico56.

Ya desde ahora se adivinan las principales dificultades que cada hipótesis va encontrar. A Downing le resultará problemático probar la semejanza de

55. F. G. Downing, Jesus and the Threat of Freedom. London 1987, 159.

56. F. G. Downing, "Word-processing in the Ancient World: the Social production and performance of Q": JSNT 64(1996)29-48. 
los cínicos con los cristianos; ya que éstos últimos profesan doctrinas como la escatología, la cristología, los milagros de Jesús, la otra vida, etc. que será difícil o imposible de probar su presencia en los cínicos. Estas dificultades no las tienen los profesores americanos; pero en su caso el problema residirá en probar que existió ese cristianismo reducido y ese Jesús "destilado" o reconstruido con tan escasa evidencia.

\section{Opinión de Downing}

Su tesis puede resumirse así: el amplio espectro de la filosofía popular conocida como cinismo encuentra muchos ecos en la enseñanza de Jesús, en la tradición sinóptica en particular y luego en la iglesia primitiva. Estas semejanzas no son accidentales. Jesús mismo acuñó su doctrina en aforismos de estilo cínico. Los que le siguieron continuaron su enseñanza en esta forma. Pablo predicó un cristianismo en un sentido menos cínico ${ }^{57}$. Durante el periodo patrístico a algunos cristianos no les disgustaba presentarse como semejantes a los cínicos. Algunos enemigos de la iglesia asociaron a los cristianos con los cínicos.

Acentúa las semejanzas y atenúa las diferencias. Para Downing el cinismo ofreció un modelo para presentar el mensaje de Jesús. No quiere decir que los evangelistas tomaron partes de la enseñanza cínica y se la atribuyeran a Jesús. Más bien ellos tomaron dichos de Jesús que iban en la dirección de los cínicos y lo presentaron con un look cínico. ¿Por qué? ¿Por estrategia comercial? Esto parece que pensaba en un primer momento ${ }^{58}$. Más tarde atenúa las diferencias entre Jesús y los cínicos y da un paso adelante: Jesús fue un predicador popular cínico59. El mundo helenista le proporcionó un vocabulario y un mundo de ideas que adoptó para comunicarse con los demás. No fue el primero que intentó un matrimonio entre judaísmo y helenismo. Jesús no presenta un puro judaísmo. Jesús presentó su propia versión del cinismo para responder a la predicación cínica que había en Galilea.

57. Ultimamente, al parecer, (véase $J B L$ 117,1998,104,nota 35) Downing piensa que hay más cinismo en Pablo de lo que antes creía. Es de suponer que defienda esta opinión en el libro recientemente publicado y que no he podido leer, Cynics, Paul and the Pauline Churches: Cynics and Christian Origins II. London, 1998.

58. "Cynics and Christians": NTS 30(1984)584-593.

59. "The Social Contexts of Jesus the Teacher: Construction or Reconstruction": NTS 33(1987)439-451. Este artículo aparece también en Cynics and christian Origins, cap. 6. 
Downing admite que no puede citarse ningún cínico que presente un modelo preciso para Jesús. Este hizo su propia selección y ofreció puntos de vista nuevos dentro de una cultura que incluye significativos elementos cínicos al mismo tiempo que muchos judíos ${ }^{60}$.

Downing cree que presentando a Jesús como cínico se le hace más moderno; un Jesús apocalíptico nos es más extraño. Esto lo expresa particularmente en un libro de carácter divulgativo61.

\section{1. Argumentos}

-La semejanza de contenidos doctrinales y de actitudes es el primer y más importante argumento a su favor. El libro Christ and the Cynics es una especie de antología de los paralelismos observados. Recorre el N. T. presentando en cada versículo o tema una amplio número de textos cínicos que a su juicio se asemejan a la frase anotada en lo alto de la página que es tomada de los evangelios y demás escritos del N.T.

-El segundo argumento es la presencia del cinismo en Galilea. Tiro y Gadara tenían escuelas cínicas. Incluso piensa que había un cinismo judío. Intenta probar que la cuarta filosofía de la que habla Flavio Josefo era cínica. Jesús pudo tener relaciones con este movimiento de liberación fundado por Judas el Galileo62.

Como sabe que durante el s. I. y durante dos siglos antes hay un silencio de las fuentes sobre personajes cínicos, Downing defiende la continuidad del cinismo aún en este periodo, asignando algunas cartas cínicas a esta época, citando los comentarios negativos sobre los cínicos de Cicerón ${ }^{63}$ e indicando que Pablo denota conocer estas ideas ${ }^{64}$.

60. "Deeper Reflections on the Jewish Cynic Jesus": JBL 117(1998)103.

61. Jesus and the Threat of Freedom. London 1987.

62. Presentó por vez primera este argumento en "The Social Contexts of Jesus the Teacher: Construction or Reconstruction": NTS 33(1987)439-451. Josefo habla de esta "cuarta filosofía en Ant. Jud. XVIII, 23-25 (cap.1.6).

63. Cynics and Christian Origins, 58ss

64. Downing insiste en que Pablo usa topoi cínicos y que hay pruebas para admitir un cinismo popular en el s. I. ("Deeper Reflections"...: JBL 117(1998) 97-104. La presencia de ideas cínicas en Pablo no es ninguna prueba a favor del cinismo de Jesús. 
-El tercer argumento ${ }^{65}$ se basa en la forma literaria de la fuente Q. Esta sigue el modelo de las vidas de los filósofos cínicos. Los ejemplos comparables, según Downing, son el libro de VI de Diógenes Laercio y la Vida de Demonacte de Luciano de Samosata, ambas contienen apotegmas y chrias. Si $\mathrm{Q}$ tiene esta apariencia es que deliberadamente fue modelada sobre ellas. La tradición cínica, en efecto, se nos ha conservado en gran parte, aunque no exclusivamente en forma apotegmática. Es difícil traducir el término chrias, o dicho sentencioso o apotegma con alguna nota biográfica. Se introduce de varios modos. Los usaron las escuelas socráticas y en su seno se originaron, pero fueron los cínicos quienes más lo desarrollaron. Parece ser que el primer coleccionista de chrias fue Metrocles ${ }^{66}$. Al parecer este tipo de anécdotas con dichos del sabio incluidos circularon desde antiguo referidas a los siete sabios.

En este punto Downing puede apoyarse en Kloppenborg quien también había expresado la opinión de que $\mathrm{Q}$ es una colección de Chrias, aunque mejor estructurada que la Vida de Demonacte ${ }^{67}$.

-Otro argumento es el modo de actuar de Jesús: Enseña en su nombre, como hace el cínico y no como los rabinos o los profetas apoyándose en Dios o en la ley. Esta confianza en sí mismo se parece mucho a la audacia cínica. Los cínicos se presentan como maestros que junto con otros que hacen las veces de discípulos llevan una vida itinerante (al menos entre los cínicos tardíos), incluyendo hombres y mujeres. El talante de Jesús es cínico: no es nada halagador, sus parábolas subvierten las normas convencionales, repudiando la sabiduría tradicional. No obstante, la terminología es judía y el material es inequívocamente judío; los puntos de controversia y los temas con los que se enfrenta, las personas a las que se dirige pertenecen al mundo judío. Tal estado de cosas solamente se explica si la tradición arranca de Jesús que adoptó un estilo cínico como asequible a todos. La otra explicación posible, a saber, que fue la comunidad cristiana la que proporcionó a Jesús un look cínico no se sostiene; no se explicaría que las comunidades cristianas varias y dispersas coincidieran en hacer estos cambios en su maestro dejando el resto como judío68. Por ello, para Downing Jesús es un cínico de Galilea que crea una amalgama de elementos de las dos tradiciones (judía y pagana), comparable

65. "Quite Like 'Q': A Genre for Q: The 'Lives of Cynic Philosophers": Biblica 69(1988)196-255. Aparece ampliado en Cynics and Christian Origins, cap. 5.

66. Diógenes LAERCIO, Vidas, VI, 33.

67. J. KLOPPENBOR, The Formation of Q. Philadelphia 1987,323-324.

68. Cynics and Christian Origins, 155-156. 
a los Oráculos Sibilinos, 4 Esdras, 2 Bar, 4 Mac, Josefo o Filón. Jesús sería un ecléctico.

No puede decirse que esta opinión y los argumentos expuestos hayan sido recibidos con aplauso. Al contrario, sus opiniones han sido repetidas veces rebatidas ${ }^{69}$. Downing mismo resume las principales objeciones que los demás le han manifestado: la lista de paralelos, breves o largos, son superficiales; el medio social donde surgen los dos movimientos (cinismo y cristianismo) es demasiado disparatado para suponer relación alguna; numerosos supuestos paralelos cínicos son más bien estoicos; los paralelos que son cínicos provienen de un tiempo tan variado que se convierten en inútiles; cristianos posteriores criticaron a algunos cínicos y temas cínicos vehementemente; al comienzo de la era cristiana hay ausencia total de cínicos; cuando en la época imperial aparecen cínicos, suelen ser citados como residentes en Roma, Atenas, Alejandría, etc.; falta de pruebas de la existencia de cínicos en Galilea; y lo que es peor aparecen siempre en centros urbanos, cosa que cuadra bien con su naturaleza de ser un fenómeno de cultura saciada ${ }^{70}$.

En cuanto a que el género literario de la fuente $Q$ se parezca a la vida de los filósofos cínicos se le advierte que efectivamente puede darse por sentado que existe en la antigüedad un tipo de vida de filósofo que toma la forma de colecciones de dichos o anécdotas del personaje en cuestión, pero no hay prueba alguna de que esta clase de vidas sea exclusiva de este tipo de filósofos. Por otra parte las vidas de los filósofos cínicos que aduce son del s. II d. C. (la de Luciano de Samosata) y del s. III d. C. (Diógenes Laercio); además éstas son una especie de random collection, es decir, no es un visible un plan ordenado; los chrias están sencillamente acumulados sin orden alguno ${ }^{71}$. Este no es el caso de Q que se muestra bastante bien estructurada con claras interre-

69. Se han manifestado en contra de Downing, entre otros, H. D. BETZ, "Jesus and the Cynics: Survey and Analysis of a Hypothesis": JR 74(1994)453-475; C. M. TUCKETT "A Cynic Q"': Biblica 70(1989)349-376; "Q and Thomas: Evidence of a Primitive "Wisdom Gospel"?': ETL 67(1991)346-360; ID., $Q$ and the History of Early Christianity: Studies in $Q$. Peabody 1996, 368-391; P. R. EDDY, "Jesus as Diogenes? Reflections on the Cynic Jesus": JBL 115(1996)449-469; N. T. WRIGHT, Christian Origins and the Question of God. Vo.II. Jesus and the Victory of God. Minneapolis 1996,66-74; B. WITHERINGTON III, The Jesus Quest, The Third Search for the Jew of Nazareth. Downers Grove 1995.58-92.

70. F. G. Downing, Cynics and Christian Origins, 4.

71. C. M. TUCKETT, $Q$ and the History of early Christianity, 380. 
laciones y con unidades mayores ${ }^{72}$. Además $\mathrm{Q}$ no tiene marco biográfico alguno, a diferencia de las vidas de lo cínicos citados.

A sus críticos Downing ha contestado repetidas veces ${ }^{73}$ y ha seguido manteniendo su opinión.

\section{2. Breve Análisis de Christ and the Cynics}

El intento del libro es aducir los textos cínicos que según él tratan los mismos temas, apuntan a las mismas conclusiones y las expresan en un lenguaje similar. A veces se muestra más categórico. Así afirma que "no sólo quiere demostrar que hay semejanzas, sino que éstas son totalmente distintivas de estos grupos, es decir, exclusivas de ambos y que no comparten con los demás" (p.1). Los cristianos debieron ser vistos quite like Cynics. Otras veces parece más condescendiente y moderado: "solamente espero que no se pueda discutir que algunos cristianos primitivos y algunos predicadores paganos radicales (vistos por otros y por ellos mismos como cínicos) debieron haber sonado igual a sus oyentes" (p. ix). (El subrayado es mío).

Desde luego el libro supone un trabajo enorme, lectura de muchas obras helenistas, atención a los párrafos significativos, comparación entre ellos, etc. $\mathrm{Al}$ autor se le debe agradecer este esfuerzo considerable.

La antología de textos cínicos se halla estructurada así. Comienza desgranando los textos de $Q$ versículo por versículo y a veces, dentro del mismo versículo, los conceptos diversos si los hay. De esta manera, Q queda repartida en 80 secciones; en cada una de las cuales aporta textos cínicos que él cree paralelos a los versículos de $\mathrm{Q}$. A continuación pasa a la presentación del material propio de Mt que reparte en 48 apartados, ilustrando los temas con los paralelos cínicos correspondientes. El evangelio de $\mathrm{Mc}$ viene a continuación repartido en 41 apartados. Downing considera a la Carta de Santiago

72. J. KLOPPENBorG, Formation, 323s. A propósito de este tema resulta interesante observar que considerar a Q como colección de Chrias (como hace Kloppenborg) va en contra de Vaage y Mack que hablan de Q como cínica, pues según Kloppenborg, los chrias en $\mathrm{Q}$ son característicos de Q2, más que de Q1. incluso sirve de criterio para distinguir los niveles. Ahora bien, Vaage y Mack basan la semejanza con los cínicos en Q1 (Cfr. TUCKETT, $Q$ and the History of Early Christianity, 382).

73. El libro Cynics and christian Origins es prácticamente un repaso a los argumentos respondiendo a las objeciones. Contesta también a las críticas de Eddy en "Deeper Reflections on the Jewish Cynic Jesus": JBL 117(1998)97-104. 
muy importante y rica en paralelos con los cínicos; por ello la coloca a continuación repartida en 37 epígrafes. Sorprendentemente Lucas no ofrece mucho material cínico, por lo que los temas más importantes los coloca en solo 25 apartados. Concede que el Evangelio de Juan apenas aporta nada; tampoco Pablo, para cuyo análisis Downing se limita a apoyarse en el conocido libro de Malherbe ${ }^{74}$.

Ya aquí podemos hacer una observación. Se habrá notado que los 80 temas de $\mathrm{Q}$ casi doblan los 48 de $\mathrm{Mt}$, que es el segundo escrito que más paralelos ofrece. Los demás evangelios se distancian más aún. $\mathrm{Q}$, pues, ofrece más paralelos que ningún evangelio y ello a pesar de ser más corta que cualquiera de ellos. Un buen motivo para que los miembros del Jesus Seminar, partidarios de un Jesús cínico se limiten solamente a Q. Los evangelios tienen, claro está, más narraciones de milagros, escatología, cristología, parábolas, controversias, historia de la pasión, apariciones, etc. Y estos temas están ausentes por lo general en los cínicos. Por lo mismo comparar a Jesús con los cínicos es primar las palabras de Jesús frente a sus actos, apreciarle como maestro más que como salvador.

Se ha dicho que el libro es como un segundo Strack-Billerbeck. A este libro se le criticaba recoger textos de los rabinos de un tiempo excesivamente amplio. Acumular textos de una lista dudosa es poco crítico. Leyéndole podía concluirse que Jesús era un rabino misnaico ${ }^{75}$. También aquí una primera ojeada impresiona y se siente uno tentado a ser favorable a la opinión del autor.

Un recuento de los índices de los textos cínicos aducidos da como resultado que los autores con mucho más citados son Dión de Prusa y Epicteto. Si se repasan los textos expresamente citados dejando a parte las citas de referencia, también sucede lo mismo: Epicteto y Dión de Prusa superan amplísimamente a los demás incluso sumados todos ellos.

Una segunda particularidad debe notarse. Distingue los textos helenistas citados en tres categorías: 60 textos los presenta en griego porque coinciden "particularly significantly with the New Testament Item under consideration"; otros más numerosos los presenta en traducción inglesa en letra grande: son los que a juicio del autor se presentan "quite striking", finalmente un

74. Paul and the Popular Philosophers. Minneapolis 1989.

75. C. A. Evans, "The Need for the 'historical Jesus'. A Reponse to Jacob Neusner's Review of Crossan and Meier": Bulletin for Biblical Reseearch: 4(1994) 131. Esta misma crítica se la hace A. Denaux a L. E. Vaage (JBL 115,1996,138). 
grupo más numeroso se ofrecen en traducción inglesa en letra pequeña (p. xi). Esta clasificación de textos es subjetiva. El lector encontrará razones que aconsejarían otra distribución. Solamente quisiera señalar que los textos presentados en griego no ofrecen contactos literarios significativos con los textos del N.T. El lector que esté acostumbrado a los contactos literarios evangélicos o del N.T. con el A.T. se sentirá decepcionado al no observar semejanza alguna del vocabulario, aunque las ideas a veces sean parecidas.

Dejando la oportunidad de tal selección me interesa señalar que de los 60 textos aducidos en griego 22 son de Epicteto y 18 de Dión, que superan con mucho el total de los textos citados, con lo que volvemos de nuevo a notar la presencia avasalladora de estos dos autores.

Ahora bien, es sabido el problema que aquí se presenta. Dión escribe a fines del s. I y comienzos del s. II. Es además conocido que su cinismo es más estoico que otra cosa. Fue un teórico de la filosofía política preconizando un poder teocrático. En el discurso IV reconoce y respeta la organización política, que para un cínico antiguo era inaceptable. En sus diálogos "diogénicos" presenta a un Diógenes totalmente idealizado: Dión modela su figura sobre la de Diógenes. Y aunque manifiesta sus simpatías por los cínicos durante un cierto tiempo de su vida, no vivió como uno de ellos, ni siquiera durante su exilio, que fue más bien un destierro dorado y desde luego nada severo a pesar de las leyendas posteriores ${ }^{76}$.

Epicteto, por su parte, es un filósofo estoico; escribe a fines del s. I d. C. y en el primer tercio del s. II. En su obra nos ha dejado una presentación del cinismo realmente espléndida. El cínico es un apóstol, un profeta, un modelo de ascetismo en grado sublime. Diógenes el Cínico es un santón pagano ${ }^{77}$. Al mismo tiempo desprecia a los cínicos de su tiempo a quienes llama "parásitos restriega-puertas, que en nada imitan a aquellos sino acaso en soltar regüeldos, lo demás nada"78. En Nicópolis donde vivio había una comunidad cristiana (Tit 3,2; Rom 15,19); conoce a los cristianos a quienes llama "galileos"; los presenta como modelos de fortaleza frente al peligro, aunque lo atribuye a un hábito irracional79.

Ante estado de cosas, surge la duda de si es legítimo proponer el cinismo de estos dos autores mayormente como inspirador del movimiento cristiano,

76. DION DE PRUSA, Discursos. I-XI; trad. de Gaspar Morocho Gayo. Madrid 1988, 32.

77. Disertaciones, III, XXII.

78. Disertaciones, III, XXII, 80.

79. Disertaciones, IV, 7,6. 
cuando son posteriores a él80. No olvidemos que Downing afirma que es Jesús mismo quien dio a su doctrina un contenido cínico. Esto sólo se puede afirmar si el cinismo que se elige para comparar remonta al s. I a. C. La diferencia entre el cinismo de los s. IV y III a. C. y el cinismo de la época imperial parece a todas luces evidente. Dión de Prusa pertenecía a la élite económica e intelectual, y Epicteto, aunque esclavo en su origen, por su formación y ejercicio de la filosofía alcanzó también la fama y la categoría elitista. Ambos distan mucho de confundirse con el cinismo popular que tanto interesa a Downing81.

Hay otra objeción que puede hacerse a Downing sobre el cinismo que él relaciona con el cristianismo. Es sabido que el cinismo del imperio está muy mezclado con el estoicismo. Downing es consciente de ello. Por ello usa muchas veces la terminología Stoics-Cynics ${ }^{82}$. Con ello justifica que en su libro cite textos de Musonio Rufo, Epicteto ${ }^{83}$, Dión de Prusa, Séneca que ante todo son estoicos.

Ahora bien, este concepto de stoic-cynic oscurece el cinismo creando una amalgama de ideas donde ya no se sabe lo que es cínico, estoico o simplemente ideas más generales de la cultura de entonces ${ }^{84}$.

Séneca tiene una carta interesante bajo este punto de vista. No menciona a los cínicos por su nombre, pero cualquier lector entiende que Séneca está contraponiendo dos modos de vida: el cínico y el estoico:

"Te prevengo que no tomes ciertas actitudes que llamen la atención en tu porte y en tu forma de vivir, como hacen aquellos que no desean el progreso

80. Un estudio de las semejanzas da como resultado que efectivamente los textos que presentan un parecido más notable con el N. T. son los textos de Epicteto y Dión. No se trata, pues, sólo de cantidad, sino de la calidad de los textos aducidos.

81. Cynics and Christian Origins, 58. Esta noción de popular Cynism es un tanto confusa. No parece que se refiera a los cínicos que llenan las calles de Alejandría y que Elio Arístides reprueba o los detestados por Juliano y Epicteto. De estos no sabemos nada. Al Cinismo lo conocemos por los textos; y estos o proceden "de dentro", es decir de simpatizantes o comprometidos con el cinismo o de enemigos. En cualquier caso no creo que haya razones para hacer una distinción entre cinismo intelectual y cinismo popular. Downing mismo reconoce que no hay distancia cultural entre la alta y culta aristocracia y las masas, ni entre la presentación del cinismo que hallamos entre los primeros y las impresiones del mismo entre los segundos(Ib., 111).

82. Cynics and Christian Origins, 29 y passim.

83. Es legítimo que cite de Epicteto, Disertaciones, III, XXII, pues aquí hace la presentación de la figura del cínico.

84 C. M. TuCKeTT, “A Cynic Q?”: Biblica 10(1989)352.nota 13; L. E. VAAGE, Galilean Upstarts. Jesus' First Followers According to Q.Valley Forgey 1994, 11. 
espiritual, sino la admiración. El porte descuidado, el cabello sin cortar, la barba un tanto desaliñada, una declarada aversión a la vajilla de plata, el jergón colocado en tierra y cualquier otra singularidad que persiga la ostentación por camino equivocado debes evitarlo ${ }^{85}$... La toga que no deslumbre de blancura, pero que tampoco esté sucia...Sigamos una vida mejor que la del vulgo, no la contraria... Esto es lo primero que garantiza la filosofía: sentido común, trato afable y sociabilidad... Por supuesto nuestro propósito es vivir conforme a la naturaleza, y va contra la naturaleza torturarse el cuerpo, desdeñar el fácil aseo, buscar el desaliño y servirse de alimentos no sólo viles, sino repugnantes y groseros" $\$$.

Las fronteras entre ambos modos de vida, el estoico y el cínico están bien delimitadas, así como lo que les une: vivir conforme a la naturaleza.

Si a esta amplitud del stoic-cynic añadimos lo dicho anteriormente sobre la variedad del cinismo, la pregunta que surge es si el término cínico aplicado a los cristianos no resulta inútil. Downing es consciente de la dificultad ${ }^{87}$. Para salir de ella acude al concepto de "semejanzas familiares" entre los cínicos, sus prácticas y sus puntos de vista. La noción permite diferencias de opinión y de estilo de vida entre ellos. De esta manera lo propio y característico del cinismo se difumina.

Esto que para muchos es una debilidad de su hipótesis, Downing la convierte en un argumento más a su favor. Downing tiene siempre una defensa preparada. La respuesta que da a las objeciones que le pone Eddy lo prueban suficientemente. Según él, Eddy recoge un catálogo de conceptos y slogans propios de los cínicos, que bastan para distinguirlos de los cristianos. Le resulta fácil contestar que en realidad no es así. Cada cínico hace su propia selección de las tradiciones "perrunas". Si se le argumenta que el cinismo es un fenómeno urbano, contestará que también hay algún cínico campesino. Si se le cita la actitud fría y agnóstica frente a la religión, citará a algún cínico que muestra una actitud más confiada en la divinidad88. Da la impresión de que ser cínico significa un modo de vida, el contrario y cualquier cosa que sea antisocial. De esta manera la falta de definición del cinismo debido a la escasa calidad de las fuentes dificulta la aceptación de la hipótesis.

85. Séneca coincide en esto con Luciano de Samosata quien critica a Peregrino por hacer las cosas por ostentación.

86. L. A. SÉnECA, Epístolas Morales a Lucilio, Lib. 1, Epíst. 5,1-4. Seguimos la traducción de I. Roca Meliá. Madrid, Gredos, 1986, T.I. p. 107.

87. Cynics and Christian Origins, 54.

88. F. G. Downing, "Deeper Reflections”, 97-104. 


\section{3. Las diferencias entre cínicos y cristianos}

Estas han sido señaladas repetidas veces, por lo que poco nuevo cabe decir. Señalemos por otra parte, que el mismo Downing encuentra algunas diferencias. Repetidas veces llama la atención sobre la ausencia entre los cínicos de tres temas cristianos: Curaciones, exorcismos e inminencia del juicio o escatología ${ }^{89}$. En otro lugar llama a estos temas some minor strains ${ }^{90}$; sin duda alguna, porque aún en estos temas cree poder encontrar algunas semejanzas entre los cínicos, diciendo que posiblemente algún cínico piadoso podía esperar que Zeus curara ${ }^{91}$, y porque advierte una cierta y vaga escatología en algunas cartas cínicas (Ps. Heráclito, 5.9; Ps. Diógenes, 39) y en Epicteto (Enquiridion 15$)^{92}$. En realidad los textos citados son muy poco significativos. El texto de Epicteto, por ejemplo, dice lo siguiente: "Siendo moderado en la comida e incluso absteniéndose, será no sólo convidado de los dioses sino su colega en el gobierno del mundo". Si detrás del texto hubiera una escatología clara y una creencia en la vida más allá de la muerte, entonces el texto podía ser tenido en consideración, pero tal como está, el texto vale poco. Downing sabe que su interpretación no es admitida ${ }^{93}$. Por ello promete artículos futuros donde probará que la visión escatológica era común en el mediterráneo oriental ${ }^{94}$.

Otro tema reconocido como ausente del cinismo es evidentemente la Cristología ${ }^{95}$, que unida al título de Hijo del hombre y la escatología forman un complejo de múltiples ramificaciones de especial importancia para el cristianismo y que el cinismo no tiene.

A esto habría que añadir otros temas de especial relieve propios del cristianismo: Jesús no tiene interés por esa libertad radical, ni antipatía fundamental hacia las leyes sociales. Jesús no se muestra contrario a los sacrificios rituales, a las tasas religiosas y gubernamentales, al matrimonio. Es falso presentarle como un enemigo de la familia sobre la base de los dichos en que exige el odio a los padres y hermanos para seguirle a él (Lc 9,59-60;14,26). Si fuera así, ¿cómo explicar la condena severa del divorcio, que manifiestamen-

89. Cynics and Christian Origins, 141.

90. Ib. 164 .

91. Christ and the Cynics, 36.

92. Cinics and Christian Origins, 140.

93. F. G. DownING, JSNT 64(1996) p.45, nota 63.

94. JSNT 55(1994) 22, nota 6.

95. Christ and the Cynics, 196. 
te es una defensa de la mujer casada?96. Tampoco consta que practicara una vida "perruna", sin pudor y recato ${ }^{97}$.

En las palabras de Jesús a los misioneros la confianza en Dios es esencial, igual que en el Padre Nuestro. Esto es lo que no cabe esperar de un cínico, pues los cínicos eran cualquier cosa menos religiosos. En Jesús el discípulo incluso para su subsistencia depende de Dios. Jesús atestigua una vida de dependencia e intimidad con Dios y entrega generosa a los demás de que carecen los cínicos. La gente de Q tiene claramente una forma de experiencia religiosa diferente de los cínicos. Bajo este punto de vista la hipótesis cínica puede ser una sofisticada manera de querer modernizar a Jesús ${ }^{98}$.

\section{4. Las Semejanzas}

Robinson ${ }^{99}$ confiesa que su interés por Jesús cínico surgió al leer en L. E. Vaage el parecido entre Q 12,22-31100 con Dión de Prusa. El texto de Dión es éste:

“¿No ves cómo las fieras y las aves por sí solas llevan una vida mucho más atinada que los hombres y también más gratificante, gozan de mejor salud, son más fuertes, cada una de ellas vive tanto tiempo como le es posible y, sin embargo, no tienen manos ni inteligencia humana?. Pero, en compensación de sus propias carencias, poseen el mayor de los bienes: no tienen propiedad privada"101.

Poner a los animales, a las plantas y en definitiva la naturaleza como ejemplos para el obrar humano era un tópico no sólo entre los cínicos sino también entre los estoicos ${ }^{102}$. Con razón Downing da importancia a la semejanza con el texto de la fuente Q citado ${ }^{103}$. Solamente que en el Evangelio el ejemplo se aduce para exhortar a la confianza en la providencia divina. Esta

96. Cfr. S. GUIJARRo OPORTO, "Reino y Familia en conflicto: una aportación al estudio del Jesús histórico": Estudios Bíblicos 56(1998)507-541, espec. 538-539.

97. San Agustín considera esta desvergüenza cínica como contraria no sólo al cristianismo, sino a la misma naturaleza humana (La Ciudad de Dios, XIV, 20).

98. J. M. RoBINson, "Galilean Upstarts", 239.

99. Ib., 224.

100. Como es habitual cuando citamos la fuente $\mathrm{Q}$ tomamos el texto de $\mathrm{Lc}$.

101. DION DE PRUSA, Discursos. X, 16. (La traducción es de Gaspar Morocho Gaya. Madrid, Gredos, 1988, 447.

102. F. G. Downing (Christ and Cynics, 70-71) cita un texto de Musonio Rufo(xv) y otros de Epicteto.

103. Cynics and Christian Origins, 12-13. 
idea es precisamente la que se echa de menos en el texto de Dión. Es cierto que la confianza en Dios se da en Epicteto ${ }^{104}$ y Musonio Rufo, pero la idea de la providencia divina es más estoica que cínica.

Un tema común a cínicos y a cristianos es el desprecio de las riquezas. "No podéis servir a Dios y al dinero"( Lc 16,13c) es una frase muy parecida a la que Diógenes Laercio atribuye al padre del cinismo (VI, 50): "La pasión por el dinero es la madre de todos los vicios". La renuncia a los bienes de este mundo es quizá una de las características que ya desde antiguo se notó unía a cínicos y cristianos ${ }^{105}$. El ámbito más común de cínicos y cristianos probablemente fue la práctica de un modo de vida ascética; pero también aquí surgen en seguida las diferencias; el fin del ascetismo cínico- la felicidad- es inmanente y seculario6.

Es frecuente que se cite la itinerancia como el elemento que visto desde fuera más asemejaría los cristianos a los cínicos. "No toméis nada para el camino, ni bastón, ni alforja, ni pan, ni plata; no tengáis dos túnicas cada uno" (Lc 9,3). "No llevéis bolsa, ni alforja, ni sandalias" (Lc 10,4). Estas consignas dadas a los discípulos reflejarían el modo de vida cínico. Dejando a un lado que el texto prohibe llevar bastón, alforja, dos cosas que precisamente constituían el atuendo típico del cínico, es claro que la austeridad y el carácter mendicante o el vivir a merced de los demás aúna a ambos modos de vida. En el evangelio el modo de vida supone y se fundamenta en el cuidado paternal de Dios; la búsqueda del reino de Dios es la riqueza mayor del seguidor de Jesús. Es dudoso, en cambio, que esta providencia divina sea el fundamentado del desprendimiento cínico. Es más bien la libertad personal lo que se busca.

Prescindiendo de si la itinerancia era tan común entre cínicos y cristianos como a veces se afirma, creemos que es conveniente recordar lo que Flavio Josefo dice de los esenios:

"No tienen una sola ciudad, sino que en todas las ciudades hay grupos numerosos de ellos. Cuando llega un miembro de la secta de otro lugar, le ofrecen sus bienes para que haga uso de ellos como si fueran propios, y se aloja en la casa de personas que nunca ha visto, como si de familiares se tratara. Por ello, viajan sin llevar encima absolutamente nada, sólo armas para defenderse de

104. Disertaciones, I, IX, 7. 9; III, XIII, 13; XXIV, 16.

105. Chr. P. Jones, "Cynisme et Sagesse Barbare": Le Cas de Pérégrinus Proteus": Le Cynisme Ancien, 310.

106. The Cynics, 19. 
los bandidos.... no se cambian de ropa ni de calzado hasta que no están totalmente rotos... muestran una piedad peculiar con la divinidad107".

Filón de Alejandría incide en lo mismo:

"No hay casa que sea propiedad de una persona en particular, ninguna que no sea en realidad casa de todos; pues, a parte de que habitan juntos en confraternidades, su casa está abierta también a los visitantes venidos de fuera que tienen el mismo ideal"108.

Señala también Filón de Alejandría su huida de las ciudades (76), el abandono de las riquezas y de los bienes personales (76-78.84-86), el amor a la virtud y el amor a los demás (84).

Downing dice que los cristianos de $\mathrm{Q}$ se parecen más a los cínicos que a los esenios, pues estos siempre podían contar con los recursos de la comunidad. Jesús y los cínicos, en cambio, no109. Pero precisamente el discurso misionero (Lc 10,3-10) espera que los itinerantes encuentren acogida y sustento en las casas y aldeas que visitan.

A mi juicio hay otros candidatos más probables que podían ser inspiradores de la práctica cristiana: los esenios estaban más cerca y tienen la misma cultura. Los cínicos no eran los únicos que rechazaban la sociedad de consumo del S. I. También los esenios rechazaban los vestidos brillantes de los cortesanos y el consumo caro. También en Palestina habría grupos para quienes la riqueza no era señal de aprobación divina.

Recorriendo el libro se puede observar paralelos interesantes, ideas afines, coincidencias que pueden asombrar y que tiene mucha razón en señalar. Si su opinión se redujera a comparar ambos movimientos y señalar las semejanzas como se hace en la historia de las religiones, prescindiendo de un origen genealógico del cristianismo respecto del cinismo, sería todo más aceptable. Los historiadores de la filosofía y otros lo han señalado. Incluso otros ejemplos podían citarse. Epicteto110 afirma que "Heracles fue proclamado hijo de Zeus y lo era, porque amaba a Dios más a que a nada". Uno puede ver aquí una idea cristiana: la filiación divina basada en el amor. Al mismo P. Lagrange llamó la atención esta coincidencia111. Curiosamente no encuentro

107. Guerra, II, 124-126.

108. Quod omnis probus, 85 .

109. Cynics and Cristian Origins, 158-159.

110. Disertaciones, II, XVI, 44.

111. “La Pilosophie religieuse d'Epictète et le Christianisme": $R B$ 9(1912)193s. 
que Downing cite este texto. Si su hipótesis se limitase a señalar ideas más o menos afines, todo sería más aceptable. Pero afirmar la dependencia genealógica del cristianismo respecto de la filosofía cínica o decir que los cristianos de $\mathrm{Q}$ son quite like cynic y luego tener que reconocer que hay profundas diferencias en temas básicos no tiene mucho sentido. Afirmar que no hay elementos esenciales (subrayado del autor) del Cinismo que falten entre los cristianos ${ }^{112}$, no aclara mucho las cosas. Conocida la variedad del cinismo, es obligatorio preguntarse: ¿Hay algo esencial en el modo de vida de un cínico?

Por lo demás su opinión siempre será muy problemática porque tiene que apoyarse en otra hipótesis difícil de verificar, a saber, la supuesta presencia de cínicos en Galilea

\section{5. ¿Galilea helenizada?}

Aunque Robinson afirme que en la hipótesis cínica la cuestión no es saber si en Galilea había cínicos, pues los partidarios de esta hipótesis no piensan en causación histórica o derivación genealógica, sino que es materia de tipología comparada113, éste no es el caso de Downing, que repetidas veces afirma que Jesús recogió su programa de varias tradiciones, entre ellas, de la cínica. La presencia del cinismo en Galilea es necesaria y por ello se esfuerza en demostrarlo.

La helenización de la Galilea ha sido y es una cuestión discutida114. Frente a la opinión anterior, M. HENGEL sostuvo que la Palestina estaba ya profundamente helenizada desde la mitad del s. II a. C. con anterioridad a los decretos de Antioco ${ }^{115}$. Esta opinión ha sido bastante general hasta los años 80 , aunque otros autores se mostraron muy críticos ${ }^{116}$. Se pensaba que especialmente Galilea estaba inmersa en una cultura cosmopolita y urbana; no podía ser una isla en el océano helenista. Se suponía que debió haber una gran

112. Cynics and Christian Origins, 54.

113. J. M. RoBINSON, "Galilean Upstarts", 227.

114. En la revista $S B L 1994$ Seminar Papers se recogen varios trabajos sobre la Arqueología y la situación social y económica de Galilea.

115. Jundentum und Hellenismus. Studien zur ihrer Begegnung unter besonderer Berücksichtigung Palästinas bis zur Mitte des 2 jh.s v. Chr. 2 Aufl. Tübingen 1973.

116. L. H. Ferldman, "How Much Hellenism in Jewish Palestine?": Hebrew Union College Annual, 57(1986)83-111. En pag.83 nota 2 menciona a otros autores que escribieron contra M. Hengel. 
diferencia entre la Alta y Baja Galilea. La primera, por ser menos transitable y predominar las inscripciones arameas y hebreas, sería una zona más conservadora; la Baja Galilea, con sus centros urbanos más ligados al Oeste helenizado y con ciudades administrativas romanas, debió proporcionar influencias culturales helenizadoras a las que los pueblos como Nazaret no podían escapar117. Los partidarios de Jesús cínico suponen precisamente este panorama: la lengua griega cada vez iba conquistando más terreno como vehículo de las ideas helenistas que se propagaban a través de las escuelas, del comercio y de la política.

Sin embargo, últimamente este panorama no es aceptado. Hay muchas razones para pensar que la Galilea igual que la Judea seguían en el s. I teniendo una cultura propia y poco permeable a la civilización helenista.

En primer lugar la Galilea no estaba tan poblada como se cree. Las cifras que se han dado son exageradas. La Galilea del tiempo de Jesús no debiera superar los 150.000 habitantes. Las dos ciudades más grandes Séforis y Tiberiades, los dos centros administrativos de la región, no debían llegar entre las dos a 15.000 habitantes ${ }^{118}$. Por tanto el ambiente de la Galilea era rural en su inmensa mayoría. El hecho de que en el s. II la población siguiera aumentando demuestra que no estaba superpoblada.

Los dos centros urbanos eran evidentemente Séforis y Tiberiades, ésta desde su fundación en torno al año $26 \mathrm{~d}$. C. La arqueología no es clara sobre si en la primera predominaba el elemento israelita o el pagano. La historia puede aportar estos datos 119 .

Se la menciona por vez primera en 103 a. C., cuando Ptolomeo Latiro, rey de Cipro, en guerra con Alejandro Janneo, conquistó varias ciudades y asedió Séforis en sábado sin poderla conquistar ${ }^{120}$. Es una prueba de su carácter israelita. Otra muestra del carácter eminentemente judío de su población fue la revuelta que prendió en la ciudad a la muerte de Herodes el año 4 a. C. La sublevación fue aplastada por el gobernador romano de Siria, Varo, siendo la ciudad destruida y sus habitantes vendidos como esclavos. No tardó Antipas en reconstruir la ciudad y sus murallas, empleando la mano de obra de las aldeas circundantes. Disponía de un palacio, acrópolis y ciudad baja y una

117. R. A. HorsLey, Archeology, History, and Society in Galilee: The Social Context of Jesus and the Rabbis. Valley Forgey, 1996, 91.

118. R. A HORSLEY, Archaeology, 45.

119. E. SCHÜRER, Historia del pueblo judio en tiempos de Jesús 175 a. C.-135 d. C.. Edición dir. y edit. por G. Vermes, F. Millar, M. Black. Madrid 1985, II, 235-240.; J. F. STRANGE, "Sepphoris": ABD, V. 1090-93.

120. Flavio Josefo, Antigüedades Judías, 13, 12, 5. 
zona de casas nobles; también poesía un teatro, aunque no se sabe si remonta al s. I o es posterior. Pero no se hicieron entonces otros monumentos propios de una ciudad romana, como los templos, el estadio, hipódromo, etc. Para muchos esta reconstrucción de la ciudad señaló el cambio profundo de su carácter cultural, ya que desde entonces se mostró siempre fiel a Roma. Además, como se sabe que Herodes en la administración empleó elementos no judíos, se supone lógicamente que Antipas haría igual, por lo que la cultura debió sufrir un cambio importante: comienzan a aparecer nombres latinos y griegos en los registros. Desde luego la población debió ser mixta, pero el elemento pagano nunca pasó de ser una capa fina, siendo la población judía predominante. Prueba de ello es que Flavio Josefo esperaba de los habitantes de Séforis que se portaran como verdaderos judíos ${ }^{121}$. De ninguna manera Séforis o también Tiberiades admiten comparación, por ejemplo, con Escitópolis y Cesarea en cuanto a la cultura urbana y cosmopolita ${ }^{122}$. De la atmósfera religiosa de la Galilea da buena cuenta la destrucción del palacio de Herodes Antipas en Tiberiades al comienzo de la guerra judía, simplemente porque contenía representaciones de animales ${ }^{123}$.

Sería de esperar que las ciudades fueran el factor más fuerte de helenización, pero de hecho consta que la influencia fue muy limitada. Dada la estructura política y económica, parece probable que la reacción y la resistencia pesara más que la asimilación y la aculturación. Las relaciones entre la urbe y el núcleo rural no son amistosas ${ }^{124}$. La economía era de subsistencia. Los campesinos producen lo que consumen y consumen lo que producen ${ }^{125}$. La costrucción de las ciudades gravó sin duda alguna la economía de los aldeanos. Este resentimiento afloró de una manera dramática en los años 66-67126.

Difícilmente ésta puede ser la clave de la atmósfera cultural en la que pudieran florecer los cínicos que de alguna manera influyeran o proveyeran modelos para los aldeanos galileos ${ }^{127}$. De hecho no se conocen cínicos en

121. Flavio Josefo, Guerra, III, 2, 4: "(Los habitantes de Séforis) prometieron (a Vespasiano) ayudarle contra sus propios paisanos". Cfr. S. FREYNE, Galilee From Alexander the Great to Hadrian. Edinburhg 1998, 123.

122. R. A. Horsley, Archeology, 59.

123. Flavio Josefo, Vida, 66-67.

124. R. MCMUllen, Roman Social Relations. New Haven 1974, 15.

125. R. A Horsley, Archeology, 120.

126. La opinión recogida en el Annual Meeting de la Society of Biblical Literature de 1993 fue que no tenía fundamento alguno suponer una Galilea helenizada en tiempo de Jesús.

127. R. A. Horsley, Archeology, 59. 
Galilea en este periodo. Lo concede el mismo Downing128. La presencia de cínicos en Galilea es una conjetura. Sólo aparecen en Tiro y Gadara, dos ciudades helenistas fuera de Galilea. De esta última son originarios Menipo (s. III a C.), Meleagro (s. I a. C) y Enómao (s. II d. C); ninguno es del tiempo de Jesús o de $Q$, y vivieron y actuaron fuera de su ciudad.

Además, el cinismo era un fenómeno urbano. Se dirigían a la población en los grandes centros urbanos. De hecho los cínicos en el s. I prácticamente sólo se encuentran en Roma y Alejandría, donde los podemos observar desengachados de la alta sociedad, burlones de la aristocracia ciudadana. $\mathrm{Su}$ existencia supone continuo contacto con la alta sociedad, a la que continuamente provocan. A este argumento responde Downing afirmando que siendo el ideal del cínico vivir como los animales, no constreñido por las convenciones sociales, es seguro que muchos cínicos llevarían su ideal a la práctica y por tanto debieron habitar en el campo; si las noticias los sitúan exclusivamente en las ciudades es porque allí habitan los que nos transmiten las noticias de ellos ${ }^{129}$. Llevado a su extremo este argumento, tampoco las aldeas eran un sitio adecuado para ellos; su lugar mejor sería vivir aislados en el campo. Pero precisamente los cínicos nunca fueron ermitaños.

Hay además una razón poderosa que hace improbable que el cinismo floreciera en Palestina. Los cínicos son fruto de una cultura asentada, ya que van contra las convenciones, desafiando y burlándose de la cultura convencional. Esto encaja mejor en una cultura convencional ya larga. Pero resulta que la cultura judía y romano-helenista eran relativamente nuevas en Galilea ${ }^{130}$. Sin duda eran tradicionales las costumbres y formas de vivir de las aldeas, pero éstas ya estaban amenazadas por las nuevas formas culturales que se estaban introduciendo. En ningún caso hay el "humus" suficiente para que el cinismo tuviera éxito.

El intento de Downing ${ }^{131}$ de asociar los cínicos a la cuarta Filosofía de la que habla Flavio Josefo' ${ }^{132}$ es un intento fallido. Lo único que les unía era el concepto de libertad. Pero no se conoce un cínico comprometido en la política ${ }^{133}$. La profunda motivación religiosa de la cuarta filosofía, al decir de Flavio Josefo, no se compadece con el escepticismo de los cínicos.

128. "Deeper Reflections": JBL 117(1998)101.

129. F. G. DownING, Cynics and Christian Origins, 82s.

130. R. A. HoRsLeY, Archeology, 179.

131. Cynics and Christian Origins, 153.

132. Antig. Jud. 18,4-10; Guerra, 2, 118.

133. C. M. TUCKETT, “A Cynic Q": Biblica 70(1989)357-8. 
Un buen medio de penetración de la cultura helenista debería haber sido la educación escolar; pero la educación era un privilegio sólo de los hijos de los más ricos. El griego fue ciertamente usado incluso entre la gente baja; pero esto no significaba mayor riesgo para la conservación de la cultura religiosa tradicional, pues es totalmente improbable que los campesinos supieran leer ${ }^{134}$. El arameo permaneció como lengua más comúnmente hablada por la mayoría de la población.

Por otra parte el saber griego, e incluso la aceptación de la cultura griega, no significaba necesariamente abandono de la religión y modo de vida judía. Un importante detalle debe mencionarse en este contexto. En 2 Mac 4,11 se dice que un tal Juan, padre de Eupólemo, fue el judío que negoció la paz con Antioco III cuando la Palestina pasó a depender de los Seléucidas a raíz de la batalla de Panias en 200 a. C. Evidentemente debía saber griego. Su hijo Eupólemo fue uno de los enviados a Roma por Judas Macabeo para negociar el tratado de amistad del 161 a. C. Otro de los enviados fue Jasón de Cirene. No sabemos si Eupólemo sabía latín. Lo cierto es que probablemente135escribió una obra sobre los Reyes de Judea en torno a los años 158 a. C. Sin duda era un personaje ilustrado, incluso helenista, pero se puso de lado de los Macabeos y luchó contra los "helenistas", es decir los partidarios de la helenización de la Palestina. Lo mismo debe decirse de Jasón de Cirene, cuya obra en cinco volúmenes fue resumida por el autor del 2 de Mac. Es claro, pues que el aprendizaje del griego e incluso la asimilación de la cultura griega, no lleva consigo un abandono de la religión y modo de vida tradicional.

Según una anécdota rabínica atribuida a Enómao, filósofo cínico y amigo del rabí R. Meir, los judíos pudieron resistir a la influencia de los gentiles, porque en sus escuelas y sinagogas los niños judíos continuaron aprendiendo la Tora ${ }^{136}$.

A favor de la penetración del helenismo y del cinismo en Palestina se suele aducir los progimnasmata o manuales para la educación que constaban

134. R. A. Horsley, Archeology, 158.

135. No es segura la identificación del Eupólemo, autor de la historia, con el Eupólemo embajador de Judas Macabeo. Cfr. L. H. Feldman "How Much Hellenism in Jewish Palestine?: Hebrey Union College Annual 57(1986)96-97.

136. S. FREYNE, Galilee. From Alexander the Great to Hadrian. 323 BCE to $135 C E$. 2nd ed. Edinburgh, 143. La anécdota es muy dudosa. No consta la existencia de sinagogas hasta el año 200 d. C. O mejor dicho, no está claro si las sinagogas tenían las finalidades civiles y religiosas que más tarde se les atribuye y si eran edificios. Sobre esto véase H. A. Mckay, "Ancient Synagogues: The Continuing Dialectic Between Two major Views": Currents in Research: Biblical Studies, 6 (1998) 103-142. Lo que parece claro es que la sinagoga no es 
de antologías de autores helenos entre los cuales figuraba Diógenes ${ }^{137}$. Esta es la razón por la que los escritores conocen las anécdotas de Diógenes138. Hay que notar que esto era para una escuela superior y para la educación pagana139. Afirma Downing que si en Galilea alguien quería aprender griego tendría que conocer la tradición cínica; esto es ir más allá de la evidencia.

El tema de la educación de Palestina es muy delicado. La primera vez que se menciona una escuela es Sir 51, 23, que ciertamente no es una escuela abierta a todos, sino sumamente elitista. Según la tradición judía Josué ben Gamla, Sumo Sacerdote (ca. 63-65 d. C.) nombró maestros en cada provincia y en cada aldea para que fueran allí niños de seis a siete años ${ }^{140}$ ¿Es reforma, o es inicio del sistema escolar? En torno a la era cristiana, parece que las escuelas están atestiguadas en la sociedad judía, especialmente en la capital: "Había 480 sinagogas en Jerusalén y cada una tenía una bet-sefer y una bettalmud, la primera para la S. Escritura, la segunda para la Mishna ${ }^{141}$. Pero no hay que imaginarse ni que fuera una escuela obligatoria ni que fuera un lugar donde se pudieran trasmitir ideas cínicas o simplemente pertenecientes a la filosofía pagana. El fundamento de toda la enseñanza era el estudio del sagrado texto; la escuela debía conducir a los hombres al conocimiento de la religión, lengua e historia del pueblo. No era su deber enseñar las ciencias profanas ${ }^{142}$. Por tanto la educación en Palestina tiene un interés bien distinto y desde luego era inaccesible para los aldeanos de la baja Galilea.

En definitiva parece que se puede afirmar que la Galilea no estaba tan helenizada como los partidarios del Jesús cínico suponen. Las creencias del judaísmo: La alianza con Dios, Israel como tierra sagrada, Ley y templo eran ideas vivas. De lo contrario no se entiende las rebeliones y guerras contra los dominadores extranjeros. Tiene razón L. H. Feldman cuando afirma que no debería preguntarse cuánto y en qué medida el helenismo penetró en Pales-

imitación de la escuela helenista, sino de la escuela egipcia ligada al templo.

137. Anécdotas de Diógenes aparecen en textos escolares. Cfr. COLLART, Le Papyrus Bouriant. Paris, 1926, 23-24.

138. La lista de autores que las conocen es numerosa. Véase H. Kusch, "Diogenes von Sinope": $R A C$, III, 1066.

139. Cfr. S. Bonner, Education in Ancient Rome from the Elder Cato to the Younger Pliny. Berkeley 1977, 250-76.

140. b. B. Bat., 21a.

141. y. Meg. 3,1.

142. Cfr. P. BLOMENCAMP, "Erziehung”: RAC VI, 520. 
tina, sino cómo los judíos resistieron ${ }^{143}$. La atmósfera que los partidarios del Jesús cínico suponen es improbable. Debe recordarse que el cinismo fue una filosofía helenista antireligiosa que se centraba en la autosuficiencia, libertad de la ley y práctica de toda suerte de conductas desvergonzadas transgrediendo las normas de la comunidad. Tales cosas violaban los más elementales puntos de vista de un judío.

\section{El cinismo de Jesús en el ámbito del Jesus Seminar}

El cinismo atribuido a Jesús en los ambientes americanos del Jesus Seminar tiene fundamentos diferentes al indicado por Downing. Tres son los autores que más se han significado, aunque el número de partidarios sigue creciendo.

Según J. M. Robinson fue durante la primavera de 1986, estando en Claremont cuando Leif E.Vaage, Ron Cameron y Burton Mack llegaron a la conclusión de que Jesús fue un sabio cínico ${ }^{144}$. En pocos años las publicaciones se sucedieron proponiendo la hipótesis con variantes importantes ${ }^{145}$. Como entre los favorables al Jesus Seminar y por consiguiente a Jesús cínico predominan los investigadores procedentes de Claremont (donde enseña J. M. Robinson) y de Harvard (donde enseña H. Koester), se ha llegado a hablar de la Harvard-Claremont Connection ${ }^{146}$. Ultimamente estos dos profesores se distancian cada vez más de las conclusiones a las que han llegado sus discípulos.

Conviene señalar algunos supuestos importantes que todos comparten:

1) La tesis de Kloppenborg sobre la división de $Q$ en tres estratos y el hallazgo ${ }^{147}$ de que el estrato más antiguo de $\mathrm{Q}(\mathrm{Q} 1)$ no tiene nada de escatológico ni de apocalíptico sino sapiencial ha sido heurísticamente fundamental.

143. "How Much Hellenism in Jewish Palestine?", 111.

144. J. M. Robinson, "Galilean Upstarts”, 223.

145. Suele citarse como el primer trabajo la disertación inédita de L. E. VAAGE, Q: the Ethos and Ethics of an Itinerant Intelligence. 1987; R. CAMERON, "What Have You Come Out to See?: Characterizations of Joh and Jesus in the Gospels": Semeia 49 (1990) 35-69; B. L. MACK, A Myth of Innocence. Mark and Christian Origins. Minneapolis 1988; ID., El Evangelio perdido. El Documento Q. Barcelona 1993. Este libro es una versión más popular del extenso libro anterior; L. E. VAAGE, Galilean Upstarts: Jesus' First Folowers According to $Q$. Valley Forge 1994.

146. W. FARMER, Gospel of Jesus: the Pastoral Relevance of the Synoptic Problem. Louisville 1994. 163.

147. R. W. FunK dice que el descubrimiento de un Jesús sapiencial no escatológico fue para los miembros del Jesus Seminar una sorpresa (Honest to Jesus, Jesus for New Millenium. New York 1996, 145). 
2) El gran aprecio del Evangelio de Tomás con su doctrina sapiencial y no escatológica es el otro punto de apoyo de la hipótesis. De esta manera Q1 y Tomás, consideradas fuentes antiquísimas, se sostienen mutuamente para alcanzar según ellos un Jesús más original.

3) Estos estratos más antiguos de la tradición de Jesús: Q1, aforismos premarcanos (B. L. Mack) y primer estrato de Tomás revelan un Jesús cuyo estilo y contenido de enseñanza son representativos del cinismo antiguo.

4) La Baja Galilea de entonces- incluyendo a Séforis- poseía una cultura helenizada, y así proveía el lugar idóneo para que Jesús entrara en contacto con la filosofía cínica.

5) El método sociológico suplanta el método histórico. Se aplican las leyes universales de la formación de un grupo social. La investigación sobre un Jesús histórico es suplantada por una investigación de los factores sociales en juego en la iglesia primitiva. Cuando se entienden los factores, la idea mítica del cristianismo primitivo acerca de Jesús y la misma idea de que el cristianismo arranca de una persona única y singular histórica es un mito del cristianismo primitivo que puede explicarse sociológicamente. Prácticamente no es que Jesús haya creado un grupo social con fines sociales, más bien las cuestiones sociales de ciertos grupos crearon a Jesús ${ }^{148}$.

6) El cristianismo primitivo desde luego fue activo en promocionar y exponer sus puntos de vista, al igual que sus semejantes los filósofos cínicos. Pero no les movía ningún motivo misionero. No tenían una misión para Israel y menos aún para el mundo. Los cristianos de Q se entendieron como los cínicos al decir de Epicteto "enviados por los dioses" para proponer otra escala de valores y su "atajo" hacia la felicidad.

\section{L. E. Vaage ${ }^{149}$}

Ha sido uno de los primeros promotores de la opinión cínica. Comparte con sus colegas americanos muchas ideas, como hemos señalado antes. Pero tiene puntos de vista propios que pasamos a exponer.

148. G. A. Boyd, Cynic Sage or Son of God. Wheaton 1995, 58.

149. Q: the Ethos and ethics of an Itinerant Intelligence. Diss. Claremont 1987: ID. Galilean Upstarts: Jesus' First Followers According to Q. Valley Forgey 1994. Esta obra recoge lo más importante de su disertación inédita. 
6. $1 . Q 1$

En primer lugar Vaage ${ }^{150}$ no propone derivar Q del cinismo. Evita así una dificultad: tener que dedicarse a cuestiones históricas sobre si la Galilea estaba helenizada o era posible el cinismo en la situación social de esta región. Jesús y Q no necesitan haber visto u oído a un cínico. La cuestión es más de religión comparada, de analogía. Entre los diversos tipos y estilos de vida, ¿a cuál se asemeja más el cristianismo primitivo? Propiamente no se trata de si la comunidad de $\mathrm{Q}$ fue cínica, sino más bien si ella se parece a los cínicos por su ethos, ideología, modelo social de identificación. Su opinión es así más sencilla, lo que supone una ventaja.

Tanto Vaage como B. L. Mack ya no insisten tanto en el itinerancia como característica de $\mathrm{Q}$, aspecto que asemejaría esta comunidad a los cínicos. Ambos se fijan más en la crítica social y contracultural, en el ethos riguroso y exigente. Esta postura crítica y desarraigada es la que manifiesta su carácter cínico. Pero las diferencias vienen a continuación. Mientras que B. L. Mack extiende su análisis a toda la fuente Q, Vaage se limita a Q1, o mejor a una reconstrucción particular suya de esta fuente.

Vaage fundamentalmente sigue la estratificación de Q expuesta por J. Kloppenborg151 y aceptada mayormente por todos los miembros del Jesus Seminar. Pero se distancia de él atribuyendo a Q1 los siguientes textos 7,2426.28a.33-34; 11,14-20.39-48.52; 13,18-21 que Kloppenborg colocaba en Q2. Por el contrario, contra la opinión de Kloppenborg Lc 10,2.7b son asignados a Q2. En un apéndice da las razones de estos cambios en los que no nos interesa ahora entrar.

\section{2. El grupo $Q 1$}

Una vez delimitado el estrato más primitivo de $\mathrm{Q}$, comenta no todos los textos, sino los más significativos para su objetivo, que no es otro que buscar la identidad social del grupo, es decir, el ethos original, el contorno cultural y el estilo de vida de la comunidad de Q1.

150. Galilean Upstarts, 10-11.

151. The Formation of $Q$. Philadelphia 1987. 
A este fin considera esencial el análisis de las instrucciones misioneras de Lc 10,3-6.9-11.16. En ellas encuentra un estilo de vida muy parecido a los cínicos grecorromanos. Son más semejantes a ellos que a cualquier otro grupo. Si es claro que no son idénticos, es también verdad que las diferencias son menores. Se ve obligado a hacer esta salvedad, porque al lado de ideas y mandatos cínicos, como conciencia de ser enviados y temor a encontrar oposición, prohibición del dinero y de sandalias, hay otros que no se casan bien con lo que sabemos de los cínicos, a saber, la prohibición de la alforja y el bastón (dos atributos de la imagen típica del cínico) y el no saludar a nadie por el camino. Si en este caso, cree salir airoso señalando que al fin al cabo es un estereotipo cínico que permite excepciones, más difícil lo tiene con Q10, 9, donde se afirma la unión entre milagro y anuncio de la venida del reino. Esta unión entre curación ${ }^{152}$ y reino de Dios le causa problemas, pues entre los cínicos la ausencia de milagros es evidente. Se atreve a citar a Menedemo ${ }^{153}$, que el mismo Downing 154 cree que se debe atribuir a la maravillosa y calenturienta imaginación del protagonista, como el mismo Diógenes da entender. No tiene sentido afirmar "que con Menedemo y su taumaturgia llegó el reino al menos de un dios"155, pues Diógenes Laercio no menciona ni el reino ni a ningún dios al igual que en los dos textos de Luciano citados por Vaage.

Esta renuncia a todas las posesiones y a los bienes de la civilización suponía para los cínicos tener que practicar la mendicidad, que la ejercitaban militantemente, denunciando de este modo la esclavitud de la vida social y urbana. Los cristianos de la fuente $\mathrm{Q}$ también esperan hospitalidad y como los cínicos se presentan como modelos de un estilo de vida más satisfactorio. Como agentes del reino de Dios iban de casa en casa y de aldea en aldea y, a cambio de la hospitalidad, les proporcionaban los beneficios de una sabiduría superior que se conceptualiza con la expresión "reino de Dios".

En un segundo capítulo examina el precepto de amar a los enemigos y las siguientes instrucciones de presentar la otra mejilla, dar la capa al que te pide el manto, etc. También aquí le interesa dibujar el cuadro del estilo de vida del grupo. Estos mandatos son entendidos por Vaage en sentido egoísta. Citando textos de Diógenes, Epicteto y Dión de Prusa afirma que no se trata de una

152. L.VAAGE (Galilean Upstarts, 156,n. 120) traduce el término asthenes por "débil". No obstante, no excluye que se trate de enfermos; si hace esta traducción es porque el término tiene un significado más amplio en la antigua filosofía moral.

153.Diógenes LAERCio, Vidas, VI,102.

154. Christ and the Cynics, 36.

155. L.E. VAAGE, Galilean Upstarts, 35. 
ética altruista ni de interés por el bien ajeno. La recomendación no intenta que el enemigo se haga amigo. Al contrario se trata de una estrategia puesta en marcha por quien se encuentra en peligro. No son manifestaciones de amor sino astucia hábil para sobrevivir, "haciéndose el muerto" como los animales. Al ser estrategia, carece de principios y por ello no impide que la próxima vez se responda al enemigo dándole su merecido. La astucia egoísta típica del cínico para evitar las desaprobaciones sociales, frecuentemente violentas, le sirve de marco para interpretar mandatos aparentemente tan altruistas. Evidentemente el grupo Q1 no es tan bueno como parece, a juicio de Vaage. Y como piensa que "los discípulos originales de Jesús en Galilea presumiblemente pensaban que eran meros seguidores de su líder" ${ }^{156}$, Jesús mismo queda salpicado.

El grupo Q ha manifestado su ideología con la expresión "Reino de Dios", que ocurre siete veces en Q1. Estos dichos del reino de Dios dibujan el modo de vida que llevan las personas de Q. Reino de Dios expresa el sentido de valor absoluto de su ethos. No simboliza la supremacía de Dios o su gobierno; el reino de Dios, como en los cínicos, expresa la revalorización del propio comportamiento. Como es común entre los miembros del Jesus Seminar, el reino de Dios no tiene nada de escatológico ni supone horizonte alguno más allá del presente. Lc 6,20b declara que el reino de Dios es del pobre, es decir, es feliz. Lo que se afirma es una inversión de valores, o dicho de otro modo, que una vida sin poder político y sin riquezas no es una desgracia, sino una auténtica felicidad. Frente a la idea común, los cínicos pensaban que la riqueza causa inquietudes; solamente la pobreza aproxima a la imperturbable felicidad. Reino de Dios es sencillamente la eudaimonia cínica, el cambio de comprensión: convertir la adversidad en alegría157. La petición "venga tu reino" se explica por la siguiente petición sobre el pan cotidiano. Para el pobre grupo de $\mathrm{Q}$ desprovisto de todo, esperar que la fortuna de los cuervos y de los lirios del campo fuera la suya podía llamarse reino de Dios; de este modo la expresión reino de Dios es pura retórica, un modo efectivo de subrayar la propia convicción y surge de la reflexión de reforzar el cambio de valores sociales que se quiere propagar.

156. L. E. VAAGE, Galilean Upstarts, 39.

157. Vaage no se da cuenta que en la segunda y tercera bienaventuranza se dice que los que tienen hambre serán saciados y los que lloran se reirán. Por tanto se les promete 


\section{3. El Jesús de L. E. Vaage}

Hasta ahora se ha tratado del grupo de Q, de su ethos y de su ideología, pero ¿qué decir de Jesús? A esto dedica Vaage el último capítulo en el que comenta textos que considera como recuerdos que los miembros de $\mathrm{Q}$ conservan de sus fundadores, Juan y Jesús.

El primer texto es Lc 7,33-34: "Porque vino Juan que no comía ni bebía y decís: tiene un demonio. Vino el Hijo del Hombre que come y bebe y decís: he ahí un hombre comilón y borracho, amigo de publicanos y pecadores".

Contra J. Kloppenborg que asignaba estos versículos a Q2, Vaage cree que pertenecen a Q1, porque aquí y en 7,24b-26.28a se da la misma importancia a Juan que a Jesús. El resto de los vv. habla de diferencias entre los dos.

Juan es presentado como un asceta y endemoniado. Esta caracterización es bastante común para calificar a los cínicos, conocidos por su vida ascética; en cuanto a lo de endemoniado Vaage no se olvida de recordar que Diógenes fue considerado por Platón como un "Sócrates enloquecido"158. Contrariamente a la usual presentación de Juan como profeta o como beduino, Vaage lo clasifica como cínico. La dieta sobre todo le identifica.

La caracterización de Jesús es bien distinta. Era un "party animal"159, amante de la crápula y de la francachela, borracho notorio en tal forma que fue recordado por esta característica. Viviendo tan a lo grande, se entiende que diga a los pobres y hambrientos que no hay que preocuparse de la comida y del vestido ${ }^{160}$. Como además se le recuerda en compañía con personas nada respetables, la imagen que aflora de la más antigua tradición es la de una especie de personaje cachondo, rebelde y amante de la jarana; sería el James Dean de los años 30 de la Galilea del S.I161. Por supuesto Vaage considera esta calificación de Jesús como fiel a la realidad.

inversión de su situación. Como la primera es paralela, reino de Dios debe significar también inversión de situación y no solo un cambio de manera de pensar.

158. DióGENES LAERCiO, Vidas, VI, 52.

159. Los miembros del Jesus Seminar piensan lo mismo: "The Fellows agreed broadly that these characterizations fit what otherwise know of John and Jesus". Cfr. R. W. FunKR. W. Hoover, And The Jesus Seminar, The Five Gospels. The Search for the Autentic Words of Jesus. New York 1993, 303.

160. J. M. Robinson nota con humor que el Jesús de Vaage haría el papel de la reina María Antonieta, quien, oyendo que el populacho se quejaba de la falta de pan, sugería que bien podían comer pasteles. Véase, "Galilean Upstarts", 237.

161. L. E. VAAGE, Galilean Upstarts, 88-89. 
A este cuadro otros textos añaden rasgos nuevos, con lo que a juicio de Vaage, el texto anterior no debe considerarse como una caricatura o una calumnia falsa. Véase sino, Lc 9,57-58:

"Uno le dijo: te seguiré a donde vayas. Y Jesús le dijo: Las zorras tienen guaridas y las aves del cielo nidos; pero el Hijo del Hombre no tiene donde reclinar la cabeza".

El dicho no tiene otra explicación que ésta: Jesús llevaba una vida de perro callejero. Cuadra bien con el dicho anterior. Una persona comilona y borracha termina durmiendo allí donde la noche le pilla. Decididamente Jesús era incorregible.

Falta aún otro rasgo que anota Lc 9,59-60:

"Otro le dijo: Déjame ir primero a enterrar a mi padre. Le respondió: Sígueme, deja que los muertos entierren a sus muertos".

Es difícil imaginar algo más subversivo e injurioso hacia la sociedad de entonces. El entierro es el momento más señalado para demostrar la piedad filial. Ignorarlo sólo revela una gran indecencia, propio de sinvergüenzas. Como confirmación de lo dicho debe leerse Lc 14,26:

"Si alguien no odia a su padre y a su madre, no puede ser discípulo mío".

El dicho comulga perfectamente con el anterior y manifiesta el carácter repugnante del que lo afirmó.

Por el contrario Juan aparece en 7,24b-26 como un personaje más serio, no es una caña agitada por el viento ni un afeminado de los que pululan por los palacios reales, ni siquiera el término profeta le califica suficientemente; es "más que profeta", es un cínico que se ha enfrentado agriamente a la cultura reinante. En Q1 no aparece como un predicador de penitencia o reformador de la tradición religiosa de Israel, sino como un crítico social valiente de la corte y de las costumbres disolutas al estilo de los mejores cínicos.

Los dichos referentes a Jesús tienen una coherencia perfecta. Y dibujan una especie de personaje impío, en términos socráticos un tábano social (social glad-fly), continuamente picando e irritando la piel de las costumbres y valores convencionales, un personaje marginal, habituado a pasar la noche allí donde cae, escasamente religioso ${ }^{162}$.

162. Galilean Upstarts, 102. CH. M. Tuckett ("On the Stratification of Q. A Response": Semeia 55, 1992, 220) quiere que Vaage explique cómo si para Q1 Jesús era un desgraciado borracho, Q2 le convierte en figura escatológica y divina. 
En otro artículo163 donde estudia los textos en lo que ocurre la expresión "Hijo del Hombre", nota que sólo dos pertenecen a Q, a saber 7,34 y 9,58, dos textos citados anteriormente y repite al juicio sobre Jesús expresado antes, no sabiendo explicar por qué a este tipo se le llamó Hijo del Hombre164. Parece sencillamente que la expresión fue un tosco deus ex machina empleado por los primeros seguidores galileos de Jesús para imaginar su propia salvación como grupo, no sabiendo aparentemente qué otra cosa se podía hacer.

Encuentra que puede parecer extraño que el Hijo del Hombre en 7,34 sea presentado como persona licenciosa y luego en 9,58 se aluda a sus costumbres austeras en el dormir. Hoy nos puede parecer una contradicción; pero en la antigüedad, no. Diógenes es presentado como pasándolo mal y al mismo tiempo acostumbraba a comer ingentes cantidades de comida y bebida, si él no las pagaba ${ }^{165}$.

A nosotros sí nos parece extraño que Juan un asceta riguroso, alimentándose escasamente con algunos vegetales y agua, sea presentado como cínico, y sea también calificado como cínico Jesús que era un tipo jaranero entregado a los placeres de la buena mesa. Se dirá que era cínico de otra especie desde luego. Yo quiero ver aquí una demostración gráfica de lo confuso que es el cinismo. El calificativo vale para un roto y para un descosido. Ocurre aquí lo que con la lengua árabe, de la que se suele decir que una palabra significa una cosa, la contraria y cualquier cosa relacionada con el sexo. Dos platónicos o aristotélicos pueden portarse en su vida de diferente manera mientras profesan la misma filosofía. Tratándose del cinismo esto es más embarazoso, ya que se entiende como un modo de vida.

\section{4. "Las vidas de Jesús más grandiosas han sido escritas con odio”166}

Es muy probable que Vaage haya leído esta frase. A lo mejor quiere hacerla realidad en su caso. De todas maneras está claro que su libro no respira ninguna simpatía por Jesús. A J. M. Robinson le parece tan mal esta siniestra enemistad hacia Jesús, que piensa que de esta manera Vaage desacredita la seria tarea que el Jesus Seminar ha emprendido167. Yo no estoy segu-

163. "The Son of Man Sayings in Q: Stratigraphical Location and Significance": Semeia 55(1992)103-129.

164. Ib. 125.

165. Ib. 125.

166. A. SCHWEITZER, Investigaciones sobre la vida de Jesús. Valencia 1990, 54.

167. "Galilean Upstarts", 240. 
ro que el Jesus Seminar tenga mucho que reprocharle a Vaage por presentar a Jesús como un alcohólico, pues ya hemos señalado anteriormente que está de acuerdo con esa caracterización. Que el Jesus Seminar imprima en gris Q $7,33-34168$, en rosa 9,58.60 y 14, 26 y en negro 14,27, mientras que Vaage los asigne a Q1, no tiene mayor importancia, cuando expresamente se afirma que reflejan bien la imagen de Jesús.

Más acertado está J. M. Robinson cuando reprocha a Vaage no ver que en 7, 33-34 se hacen dos presentaciones paralelas de Juan y Jesús introducidas ambas en forma de cita.

"Porque ha venido Juan el Bautista que no comía ni bebía vino y decis: Demonio tiene.

Ha venido el Hijo del hombre que come y bebe,

y decís: ahí tenéis un comilón y un borracho, amigo de publicanos y pecadores".

Evidentemente los cristianos de Q no se identifican como seguidores de un borracho y no están de acuerdo con ninguna de las dos afirmaciones; por eso las ponen en boca de los adversarios de Q. Es muy libre Vaage de estar de acuerdo con los enemigos de Jesús, pero tendrá que explicar por qué un borracho tuvo seguidores entusiastas que se sintieron obligados a continuar su labor con un modo de vida austero, tan contrario al de su maestro. Lo que los seguidores de $\mathrm{Q}$ atribuyen a Jesús (basta una ojeada ligera a la fuente) dista a todas luces de esa figura desaprensiva y sinvergüenza. Por el contrario es perfectamente normal que la sociedad contemporánea tratara de desacreditar a Jesús y a fe que lo hizo no sólo en esta ocasión sino también en su labor milagrera (Q 11,14ss).

La prohibición de llevar provisiones (Q 10,4) por parte de una persona que banqueteaba no significa que Jesús fuera un desaprensivo, sino que es una muestra de la confianza en Dios que le movía. Esta confianza en Dios es precisamente lo que no tenían los cínicos y que no advierte Vaage.

La obtención de esta imagen de Jesús ha sido obtenida entendiendo los textos de una manera curiosa. Veamos, por ejemplo, Q9, 58:

"Las zorras tiene guarida y las aves del cielo lugar de reposo; pero el hijo del hombre no tiene dónde reclinar la cabeza".

168. J. Kloppenborg atribuye estos vv. a Q2 porque cree ver en ellos una aplicación e interpretación de Q 7,31-32, y porque aparece la hostilidad propia del estrato redaccional. 
Hemos visto que Vaage entiende este texto literalmente. Jesús dormía en la calle donde la noche le cogía.

Ahora bien el carácter metafórico e hiperbólico del dicho es innegable. No tiene sentido decir que Jesús no tenía lugar dónde dormir; podía tener al menos el mismo o parecido lugar que las zorras y los pájaros. Tiene sentido el dicho si se considera a la luz de 10,5 ss donde se exhorta a los discípulos a procurar ser recibidos en sus casas por los compañeros en la fe ${ }^{169}$. Parecida interpretación debe hacerse de Q 9,59: "Déjame ir primero a enterrar a mi padre". Le respondió: " Deja que los muertos entierren a sus muertos". Como claramente indica el adverbio "primero" se trata de prioridades. Jesús invita al quebrantamiento de las normas más relevantes de piedad. La prioridad para Jesús reside en otra parte. Es tan innegable el carácter hiperbólico de este dicho como el del anterior. Por eso se han colocado juntos. Sería un error sacar de aquí o de Q 14,26s que la característica de los seguidores de Jesús y de Jesús mismo era un ethos antifamiliar propio de desarraigados y sin hogar. No debe olvidarse de que la itinerancia de la que hablan las instrucciones misioneras, siempre se trata de una itinerancia menor, puesto que las aldeas de Galilea se encuentran todas a poco kms. ${ }^{170}$.

El traslado de Jesús al mundo cultural grecorromano, concretamente cínico, en Vaage tiene por resultado presentar a Jesús, hábil estratega, calculador frente a la hostilidad, astuto que no invierte gratis nada. Esta figura ha sido obtenida prescindiendo de contenidos importantes de Q1: confianza en Dios, oración, amor a los demás, cercanía a los pobres, recuperación de las víctimas, trato frecuente con los marginados por la sociedad, etc.

\section{B. L. Mack ${ }^{171}$}

Aunque califica de cínico a Jesús, este tema es bastante marginal en Mack. Su Jesús es un cínico borroso y oscuro, tan oculto tras los diferentes

169. J. SCHRÖTER, Erinnerung an Jesu Worte. Studien zur Rezcption der Logienüberlieferung in Markus, $Q$ und Thomas (WMANT 76). Neukirchen 1997,154-158.

170. Cada vez se da menos importancia a la itinerancia en $Q$. Se muestra contrario $R$. A. Horsley (Sociology of Jesus Movement. 2 ed. New York 1994, 117); J. Kloppenborg no le da importancia ("The Sayings Gospel Q: Recent Opinion on the People Behind the Document": Currents in Research: Biblical Studies, 1(1993)22.

171. B. L. MACK, A Myth of Innocence: Mark and Christian origins. Philadelphia 1988; ID., El Evangelio perdido. Barcelona 1994. 
grupos cristianos que apenas tiene importancia. Lo que a Mack interesa es la emergencia del cristianismo y la mitificación desarrollada reflejo de los cambios sociales experimentados; y como su disposición hacia el Evangelio y su influencia en el mundo occidental es muy negativa, el libro es un alegato en todo regla contra el cristianismo y su influencia en el Occidente.

Define su libro como ensayo ${ }^{172}$; con ello se quiere decir ordinariamente que el autor se abandona a intuiciones y a hacer grandes construcciones sin someterse a la penosa tarea de probar las afirmaciones. Y efectivamente el lector lo advertirá rápidamente.

Su opinión sobre los orígenes del cristianismo se fundamenta en teorías que es preciso tener en cuenta para entender sus conclusiones.

Mack es "deconstruccionista derridiano". Para Derrida hay que partir de los textos y abandonar la idea de libros. Los textos son anónimos, artificiales; hay que abrirse al texto, no privilegiar la voz (la metafísica de la presencia), sino la escritura, la tesitura. Hay que romper el libro para poner al desnudo la superficie del texto. Deben abandonarse los tipos de lecturas tradicionales, que en general se limitan a repetir el texto y a buscar cosas que van más allá del texto (intención del autor, contexto social, destinatarios, significados trascendentales. etc.). Para él "no hay fuera-texto". No hay más que escritura, significados substitutivos que se encadenan y no hacen presente lo real. La deconstrucción consiste en invertir el proceso con el que ha sido construido el texto, desmontarle mediante la diferancia, individuar las oposiciones, desenmascararlas, e invertir la jerarquía. No hay coexistencia pacífica sino jerarquización violenta.

Es sabido que el método redaccional intenta sorprender el sentido de un texto fijándose en aquellas partes atribuibles al último redactor. Este autor ha usado materiales anteriores que ya tenían su sentido. Averiguar el sentido de estas formas literarias era el objetivo de la crítica formal. Precisamente la diferencia, la diferancia en términos derridianos es el objetivo de la lectura deconstruccionista que consiste en imaginar un método que combina la crítica formal y redaccional de una manera más sofisticada. No va a fijarse exclusivamente en las unidades dispares incluidas en el texto, ni tampoco en la coherencia y unidad del texto, sino en la tensión, en el juego violento entre los dos polos. Los evangelistas luchan por imponer su voz sobre las unidades y al mismo tiempo las unidades se resisten a ser silenciadas en la obra. Así cambia el paradigma. No debemos imaginar que las tradiciones orales se juntan y son

172. A Myth, xiii. 
asimiladas en los textos, sino que nos debemos fijar en cómo estas tradiciones dejan su firma en las obras. El texto habla con voces contrapuestas en amplia desarmonía, señalando la presencia de otros. En el movimiento entre integración y desintegración emerge la diferancia173.

Otro tema importante en Mack es la idea de mito y mitología y el papel sociológico que juega en los grupos y comunidades. En este tema depende de la aproximación cultural-antropológica de la religión de J. Z. Smith. Se ha sentido impactado por lo que ha encontrado en este autor sobre la idea de mito religioso y el ritual como racionalización mítica de la formación social de un grupo. Mitos y rituales son siempre resoluciones de conflictos y tratan de la identificación de un grupo dentro de una comunidad. Los mitos determinan qué es un grupo, qué conducta es apropiada, quién manda y quién no, qué valores hay que establecer y cuáles no. Todo el libro de Myth of Innocence ha sido construido desde esta perspectiva. El mismo dice que la J. Z. Smith y su teoría de la religión informa la posición del libro. Para Smith, lo que llamamos religión es un modo social de pensar sobre la identidad y la actividad de un grupo ${ }^{174}$. La formación social y la identidad no son parte de la religión, son la religión. Por lo tanto, las creencias religiosas, los símbolos y los ritos no son realmente lo que parecen, únicamente son modos de pensar acerca de las prácticas sociales. Lo que en realidad hacen es establecer la identidad social. "Los evangelios no son historias... son mitos que reivindican para sí ser historias"175. La única historia contenida en los evangelios es la historia de la creación de la comunidad y sus conflictos.

\section{(Continuará)}

C. Mielgo

Estudio Teolgico Agustiniano

Valladolid

173. D. SEELEY, Deconstructing the New Testament. Leiden 1994, 16-19.

174. A Myth, 20, nota 9.

175. B.L. MACK, "Innocent Transgresor: Jesus in Early Christian Myth and History": Semeia 33(1985) 155. 